\title{
Title: Evolution of alluvial mudrock forced by early land plants
}

One Sentence Summary: A global stratigraphic shift in alluvial mudrock abundance reflects a sediment flux revolution, as Earth evolved into a vegetated planet.

\author{
Authors: William J. McMahon ${ }^{1}$, Neil S. Davies ${ }^{1 *}$
}

Affiliations: ${ }^{1}$ Department of Earth Sciences, University of Cambridge, Downing Street, Cambridge CB2 3EQ, United Kingdom.

\section{*Correspondence to: $\underline{\text { nsd27@cam.ac.uk }}$}

Abstract: Mudrocks are a primary archive of Earth history from the Archean to recent, and their source-to-sink production and deposition plays a central role in long-term ocean chemistry and climate regulation. Using original and published stratigraphic data from all of Earth's 704 Archean- $(3.5 \mathrm{Ga})$ to Carboniferous- $(0.3 \mathrm{Ga})$ aged alluvial formations, we prove contentions of an upsurge in the proportion of mud retained on land coeval with vegetation evolution. We constrain the onset of the upsurge to the Ordovician-Silurian and show that alluvium contains on average 1.4 orders of magnitude greater mudrock after land plant evolution than it does in the preceding $90 \%$ of Earth history. We attribute this shift to the ways in which vegetation revolutionized mud production and sediment flux from continental interiors.

Main Text: Earth's stratigraphic record preserves a number of trends in biogenic and chemogenic sedimentary rock type through time, reflecting secular changes at the surface of the planet (1). Siliciclastic sediments, primarily produced by the mechanical and chemical breakdown of parent rock, do not have such first order biological controls. However, subtle secular changes have been previously quantified, including both clay mineral evolution (2) and (bio)geomorphic sedimentary structures and architecture (3-5). In terms of bulk lithology, it is a 
long-held anecdotal contention $(4,6-8)$ that mudrock is rare in alluvium that was deposited prior to the evolution of land plants, but common thereafter. We quantitatively test this contention and find it to be true, demonstrating the magnitude and timing of onset of the increase, using data recording the proportional thickness of mudrock within alluvial stratigraphic sections (Fig. 1A).

Data were collated from a survey of Earth's 704 globally-distributed Archean-Carboniferous alluvial stratigraphic units, reduced and analysed from 1196 published reports and 125 original field investigations. They show that mudrock is a negligible component of alluvial strata deposited during the first c. 3.0 Ga of Earth's sedimentary rock record, but common or dominant after the middle Paleozoic (mudrock defined lithologically; all rocks dominantly composed of detrital and weathered sedimentary grains, $<=0.063 \mathrm{~mm}$ (siltstone) (9)). In Archean (4000-2500 Ma) strata, the cumulative stratigraphic proportion of mudrock within alluvial strata ranges between 0-14\% (median: 1.0\%), whereas in Carboniferous (359-299 Ma) strata the range is 090\% (median: 26.2\%) (Fig. 1D). LOESS regression analysis of the data constrains the upsurge between the Late Ordovician and Devonian (458-359 Ma) (Fig. 1B), after which interval the range and average proportion of mudrock in alluvium never reverted to the same low values that characterised the first $3 \mathrm{Ga}$ of Earth's stratigraphic record. Subsampling of the data shows that, relative to Archean to Middle Ordovician (3500-458 Ma) values, the amount of mudrock was 1.1 orders of magnitude greater in the Late Ordovician to Silurian (458-419 Ma), 1.3 in the Early to Middle Devonian (418-379 Ma), 1.45 in the Late Devonian to early Carboniferous (378-339 Ma), and 1.75 in the middle to late Carboniferous (338-299 Ma) (Fig. 1C).

This stratigraphically unidirectional upsurge in alluvial mudrock likely rules out a cause due to episodic or cyclic geological phenomena (such as tectonic or climatic controls) that persisted on the Earth throughout the Archean to Carboniferous $(10,11)$ (Fig. S11). The first $3 \mathrm{Ga}$ of the 
interval we studied witnessed multiple alternations between icehouse and greenhouse conditions (12), the assembly of at least two supercontinents (13) and 16 known regional orogenies (14). None of these events had any apparent influence on the near-uniform global scarcity of preserved alluvial mudrock. Similarly, the onset of the trend does not correlate with other prominent potential triggers in the geological record. For example, it post-dates Paleoproterozoic oxygenation by at least $1640 \mathrm{Ma}$ (15), Neoproterozoic oxygenation by $142 \mathrm{Ma}$ (15) and the advent of microbial life on land by $2540 \mathrm{Ma}$ (16), and may pre-date the increased survivorship of non-marine strata by up to $60 \mathrm{Ma}(11,17)$. The systematic misidentification of pre-Ordovician mudrock as marine in previous studies is a potential source of uncontrolled bias in the study (11). However, by testing the data against various alternative hypotheses (11) (Figs S5-S8, S11-S13), we argue that the most plausible explanation is that pre-vegetation Earth had unique syndepositional controls on sedimentation, which discouraged the production or accumulation of alluvial mudrock. The trend mirrors the fossil plant record (18-20) and the appearance of primitive plants would have introduced three mechanisms important for producing mudrock-rich alluvial strata. Plants lead to an increased production of the directly-weathered fraction of fines (clays) $(2,18,21-26)$. They also increase retention of all (weathered and detrital) fines in continental deposystems, through binding (i.e., the fastening of masses of grains by plant parts such as roots) (25-26). Finally, the process of baffling (i.e., the capture and forced deposition of grains from within a moving fluid passing over and around plant parts) also increases retention of all (weathered and detrital) fines in continental deposystems (27-28).

Terrigenous fines are sourced into sedimentary systems through the mechanical mass wasting of chemical weathering profiles, supplying both weathered and detrital silt, mud and clay particles (21). Land plants are not a necessary pre-requisite for the mechanical production 
of fines, and abiotic, microbial and fungal processes could all promote the silicate weathering of clays on pre-vegetation Earth $(16,18,21,29-30)$. The presence of minor mudrock in alluvium of all ages demonstrates these alternative pathways (Fig. 1A), in addition to known terrigenous mudrocks from pre-vegetation lacustrine and marine facies. However, land plants do promote the production of clay minerals and the depth of chemical weathering profiles by increasing atmosphere-substrate connectivity through rooting, the direct secretion of organic acids and chelates, and by developing symbiotic relationships which increase the capacity of Cyanobacteria and Fungi to dissolve soil grains $(2,18,21-26)$. The degree to which the earliest bryophyte-grade plants could have boosted silicate weathering $(16,22-23,31-32)$ remains a point of debate, but a clear global intensification followed the evolution of a deeper-rooted Devonian flora $(18,22,24-25)$. The initial range expansion of mudrock proportions in the OrdovicianSilurian (Fig. 1B) suggests that even the earliest plants played some role in promoting mudrock in alluvium (26), before the dramatic rise seen after the Devonian evolution of rooting. However, even if the earliest bryophytes increased weathering, net production alone may not account for the trend. In limited instances where mudrock type has previously been distinguished, siltstone abundance exhibits the same unidirectional trend as mudstone, claystone and shale abundance (11) (Fig. S2), suggesting that even fines with a greater (though not exclusive) propensity to have been abiotically/mechanically-generated (i.e., siltstones) (21) are diminished in pre-vegetation alluvium.

Prior to vegetation, continents were colonized by microbial mats (16), but the lack of belowground structure to these communities meant that they were prone to undercutting and reworking by fluvial channels, so had a negligible effect on the retention of sediment (33). In contrast, the establishment of root systems offered novel mechanical protection against the erosion of 
sediment in alluvial settings $(23,25)$ and would thus have promoted the physical retention of clay, mud and silt. This importance of below-ground stabilization would clearly have played some role in the major Devonian upsurge in mudrock, but the root systems of earlier land plants were limited $(18,23)$, so this is an unlikely explanation for observed mud-rich Ordovician and Silurian formations.

The above-ground structures of even shallow-rooted and small-stature vegetation today can reduce near-surface flow of water and wind below a critical velocity that promotes sediment deposition (27-28). Observations of mosses and liverworts show effective trapping of individual fine grains between their stems, leaves and thalli, incorporating sediment into cryptogramic ground covers (26). Even though direct physiological analogy between modern and early land plants may be inappropriate (18), the earliest above-ground plant structures must have introduced a wholly unprecedented biological component of roughness to the Earth's surface. This suggests a large role for baffling by even primitive above-ground plant constructions, promoting the recurrence frequency of deposition of fines in the alluvial realm, and contributing to the mudrock increase.

The Paleozoic increase in alluvial mudrock is an important characteristic of the global sedimentary geological record. The timing with the appearance of plants is unlikely to be a coincidence as plants can greatly contribute to the development and retention of alluvial mudrocks. The source-to-sink deposition of pre-vegetation mud was thus profoundly different to that seen at the present day (34). On pre-vegetation Earth, all fines had limited potential for final (preserved) deposition within continental conduits, regardless of any non-vegetation related variations in chemical weathering intensity $(29-30,35)$ or sediment flux (36). Archean to Middle Ordovician marine settings would have received a generally greater flux of whatever terrigenous 
fines were being produced in continental source areas. After the Late Ordovician, and accentuated after the Devonian, an increasing proportion of terrigenous fines were both 1) produced and/or 2) retained on the continents: thus the marine realm may have received diminished fraction of total continentally-weathered fines. Yet this need not necessarily have equated to a diminished volume because net production at source would have been greater. A fuller understanding of mudrock in the absence of vegetation is prerequisite for any studies that invoke ancient terrestrial mudrock strata as a primary archive of geochemical or petrological data, and will have implications for the context and nature of mudrocks increasingly known from non-vegetated planets such as Mars $(8,37)$.

\section{References and Notes}

1. Erikkson, P.G. et al. Secular changes in sedimentation systems and sequence stratigraphy. Gond. Res. 24, 468-489 (2013).

2. Hazen, R.M. et al. Clay mineral evolution. Am. Mineral. 98, 2007-2029 (2013).

3. Dietrich, W.E., Perron, J.T. The search for a topographic signature of life. Nature 439, 411-418 (2006).

4. Davies, N.S., Gibling, M.R. Cambrian to Devonian evolution of alluvial systems: The sedimentological impact of the earliest land plants. Earth-Sci. Rev. 98, 171-200 (2010).

5. Davies, N.S., Gibling, M.R. Evolution of fixed-channel alluvial plains in response to Carboniferous vegetation. Nature Geos. 4, 629-633 (2011).

6. Winston, D. Fluvial Systems of the Precambrian Belt Supergroup, Montana and Idaho, U.S.A. Fluvial Sedimentology Memoir, 5, 343 (1977). 
7. McCormick, D.S., Grotzinger, J.P. Distinction of marine from alluvial facies in the Paleoproterozoic (1.9 Ga) Burnside Formation, Kilohigok Basin, N.W.T., Canada. J. Sediment. Petrol. 63, 398-419 (1993).

8. Grotzinger, J.P. et al. A habitable fluvio-lacustrine environment at Yellowknife Bay, Gale Crater, Mars. Science, 343, 1242777 (2014).

9. Ilgen, A.G. et al. Shales at all scales: Exploring coupled processes in mudrocks. EarthSci. Rev. 166, 132-152 (2017).

10. Davies, N.S. et al. Discussion on 'Tectonic and environmental controls on Palaeozoic fluvial environments: reassessing the impacts of early land plants on sedimentation'. $J$. Geol. Soc. 174, 947-950 (2017).

11. Materials and Methods are available as Supplementary Materials on Science Online.

12. Hoffman, P.F. Pan-glacial - a third state in the climate system. Geology Today 25, 100107 (2009).

13. Bradley, D.C. Secular trends in the geologic record and the supercontinent cycle. EarthSci. Rev. 108, 16-33 (2011).

14. Torsvik, T.H., Cocks, L.R.M. Earth History and Palaeogeography (Cambridge University Press, Cambridge, 2016).

15. Lyons, T.W., Reinhard, C.T., Planavsky, N.J., The rise of oxygen in Earth's early ocean and atmosphere. Nature 506, 307-315 (2014).

16. Lenton, T.M., Daines, S.J. Matworld - the biogeochemical effects of early life on land. New Phytol. 215, 531-537 (2017).

17. Peters, S.E., Husson, J.M. Sediment cycling on continental and oceanic crust. Geology 45, 323-326 (2017). 
18. Boyce, C.K., Lee, J.-E. Plant Evolution and Climate over Geological Timescales. Annu. Rev. Earth Planet. Sci. 45, 61-87 (2017).

19. Rubinstein C.V. et al. Early Middle Ordovician evidence for land plants in Argentina (eastern Gondwana). New Phytol. 188, 365-369 (2010).

20. Matsunaga, K.K.S., Tomescu, A.M.F. Root evolution at the base of the lycophyte clade: insights from an Early Devonian lycophyte. Annals of Botany 117, 585-598 (2016).

21. Nesbitt, H.W., Fedo, C.M., Young, G.M. Quartz and Feldspar Stability, Steady and NonSteady-State Weathering and Petrogenesis of Siliciclastic Sands and Muds. The J. of Geol., 105, 173-191 (1997).

22. Quirk, J., et al. Evolution of trees and mycorrhizal fungi intensifies silicate mineral weathering. Biol. Lett., 8, 1006-1011 (2012).

23. Edwards, D., Cherns, L., Raven, J.A. Could land-based early photosynthesizing ecosystems have bioengineered the planet in mid-Palaeozoic times? Palaeontology 58 , 803-837 (2015).

24. Morris, J.L. et al. Investigating Devonian trees as geo-engineers of past climates: Linking palaeosols to palaeobotany and experimental geobiology. Palaeontology, 58, 787-801 (2015).

25. Xue, J. et al. Belowground rhizomes in paleosols: The hidden half of an Early Devonian vascular plant. Proc. Natl Acad. Sci. USA, 113, 9451-9456 (2016).

26. Mitchell, R.L. et al. Mineral weathering and soil development in the earliest land plant ecosystems. Geology, 44, 1007-1010 (2016).

27. Gurnell, A. Plants as river system engineers. Earth Surf. Process. Landforms 39, 4-25 (2014). 
28. Moor, H. et al. Towards a trait-based ecology of wetland vegetation. The Journ. Ecol. 105, 1623-1635 (2017).

29. Tosca, N.J., et al. Clay mineralogy, organic carbon burial, and redox evolution in Proterozoic oceans. Geochim. et Cosmo. Acta, 74, 1579-1592 (2010).

30. Kennedy, M. et al. Late Precambrian oxygenation; inception of the clay mineral factory. Science, 311, 1446-1449 (2006).

31. Quirk, J. et al. Constraining the role of early land plants in Palaeozoic weathering and global cooling. Proc. R. Soc. B, 282, 20151115 (2015).

32. Porada, P. et al. High potential for weathering and climate effects of non-vascular vegetation in the Late Ordovician. Nature Comm., 7, 12113 (2016).

33. McMahon, W.J., Davies, N.S., Went, D.J. Negligible microbial matground influence on pre-vegetation river functioning: Evidence from the Ediacaran-Lower Cambrian Series Rouge, France. Precam. Res., 292, 13-34 (2017).

34. Leithold, E.L., Blair, N.E., Wegmann, K.W. Source-to-sink sedimentary systems and global carbon burial: A river runs through it. Earth-Sci. Rev., 153, 30-42 (2016).

35. Corcoran, P.L., Mueller, W.U. "The effects of weathering, sorting and source composition in Archean high-relief basins: examples from the Slave Province, Northwest Territories, Canada." in Precambrian Sedimentary Environments: a modern approach to ancient depositional systems (Blackwell, Oxford, 2002) pp. 183-211.

36. Peters, S.E., Gaines, R.R. Formation of the 'Great Unconformity' as a trigger for the Cambrian explosion. Nature, 484, 363-366 (2012).

37. Schieber, J. et al. Encounters with an unearthly mudstone: Understanding the first mudstone found on Mars. Sedimentology 64, 311-358 (2017). 
38. Web of Science Service for UK Education. http://wok.mimas.ac.uk

39. Georef. http://www.agiweb.org/georef/

40. Google Scholar. https://scholar.google.com/

41. The BGS Lexicon of Named Rock Units. http://www.bgs.ac.uk/lexicon/

42. USGS National Geologic Map Database. http://ngmdb.usgs.gov/Geolex/geolex_home.html

43. WEBLEX Canada. http://weblex.nrcan.gc.ca/weblexnet4/weblex_e.aspx

44. Australian Stratigraphic Units Database - Geoscience Australia. http://dbforms.ga.gov.au/www/geodx.strat_units.int

45. Gradstein, F.M., Ogg, J.G., Hilgen, F.J. On The Geological Time Scale. Newsletters on Stratigraphy 45/2, 171-188 (2012).

46. Ronov, A.B. Phanerozoic transgressions and regressions on the continents: A quantitative approach based on areas flooded by the sea and areas of marine and continental deposition. Am. J. of Sci. 294, 777-801 (1994).

47. Ulmer-Scholle, D.S., Scholle, P.A., Schieber, J., Raine, R.J. A Color Guide to the Petrography of Sandstones, Siltstones, Shales and Associated Rocks. (American Association of Petroleum Geologists, Tulsa, OK, 2014).

48. Dalrymple, R.W., Narbonne, G.M., Smith, L. Eolian action and the distribution of Cambrian shales in North America. Geology 13, 607-610 (1985).

49. Davies, N.S., Gibling, M.R., Rygel, M.C. Alluvial facies during the Palaeozoic greening of the land: case studies, conceptual models and modern analogues. Sedimentology $\mathbf{5 8 ,}$ 220-258 (2011). 
50. Weissmann, G. et al. Fluvial form in modern continental sedimentary basins: Distributive fluvial systems. Geology 38, 39-42 (2010).

51. Fielding, C.R. et al. Tributary, distributary and other fluvial patterns: What really represents the norm in the continental rock record? Sedimentary Geology 261-262, 15-32 (2012).

52. Sadler, P.M. Sediment Accumulation Rates and the Completeness of Stratigraphic Sections. The J. Geol. 89, 569-584 (1981).

53. Nyberg, B., Howell, J.A. Is the present the key to the past? A global characterization of modern sedimentary basins. Geology 43, 643-646 (2015).

54. Rubinstein, R.Y., Kroese, D.P. Simulation and the Monte Carlo method. John Wiley \& Sons (2016).

55. Press, W. H., Flannery, B. P., Teukolsky, S. A., Vetterling, W. T. Kolmogorov-Smirnov Test. Numerical recipes in FORTRAN: the art of scientific computing, 617-620 (1992).

56. Alroy, J. et al. Phanerozoic trends in the global diversity of marine invertebrates. Science 321, 5885 (2008).

57. Miall, A.D. The Geology of Fluvial Deposits. Springer (1996).

58. Miall, A.D. Fluvial Depositional Systems. Springer (2014).

59. Davies, N.S. et al. Marine influence in the Upper Ordovician Juniata Formation (Potters Mills, Pennsylvania): implications for the history of life on land. Palaios 25, 527-539 (2010)

60. Davies, N.S., Gibling, M.R. Early Cambrian metazoans in fluvial environments, evidence of the non-marine Cambrian radiation: COMMENT. Geology 40, 270 (2012). 
61. Weller, O.M., St-Onge, M.R. Record of modern-style plate tectonics in the Palaeoproterozoic Trans-Hudson orogeny. Nature Geoscience 10, 305-311 (2017). records below glacioeustatic exposure surfaces. Geology 43, 59-62 (2015).

63. Berner, R.A. The Phanerozoic Carbon Cycle: CO2 and O2. Oxford, UK: Oxford Univ. Press (2004).

64. Clarke, J.T., Warnock, R.C.M., Donoghue, P.C.J. Establishing a time-scale for plant evolution. New Phytol. 192, 266-301 (2011).

65. Karol, K.G., McCourt, R.M., Cemino, M.T., Delwiche, C.F. The closest living relatives of land plants. Science 294, 2351 (2001).

66. Watchorn, M.B. Fluvial and tidal sedimentation in the 3000 Ma Mozaan basin, South Africa. Precamb. Res. 13, 27-42 (1980).

67. Andersen, L.S., Unrug, R. Geodynamic evolution of the Bangweulu Block, northern Zambia. Precamb. Res. 25, 187-212 (1984).

68. Daly, M.C., Unrug, R. The Muva Supergroup in Zambia-a craton to mobile belt sedimentary sequences. Trans. Geol. Soc. S. Afr. 85, 155-165 (1982).

69. Fralick, P., Zaniewski, K. Sedimentology of a wet, pre-vegetation floodplain assemblage. Sedimentology 59, 1030-1049 (2012).

70. Khalaf, E.E.D.A.H. Stratigraphy, facies architecture, and palaeoenvironment of Neoproterozoic volcanics and volcaniclastic deposits in Fatira area, Central Eastern Desert, Egypt. J. Afr. Earth Sci. 58, 405-426 (2010).

71. Fambrini, G.L., Janikian, L., de Almeida, R.P., Fragoso-Cesar, A. Evolução tectônica e estratigráfica do Grupo Santa Bárbara (Ediacarano) na Sub-Bacia Camaquã Central, RS, 
sul do Brasil: registro de sedimentação continental na assembléia do Gondwana. Comunicaçõe Geológicas 101, 39-54 (2014).

Acknowledgements M.R. Gibling is thanked for assistance with Palaeozoic data during the course of a previous project. O. Shorttle and J.P. Mattern are thanked for advice on the statistical treatment of the data. Funding: W.J.M. was funded by Shell International Exploration and Production B.V under Research Framework agreement PT38181. Author contributions: Both authors contributed equally to the collection and analysis of the field and literature data presented. Competing interests: There are no competing interests. Data and materials availability: A fully referenced list of the data reported in this paper is included in the Supplementary Materials.

\section{Fig. 1. Range and maximum proportion of mudrock in alluvial successions increases} dramatically after the evolution of vegetation. Proportion of mudrock within alluvial successions (\% of vertical stratigraphic thickness) plotted against geologic age (x-axis scaled to numerical ages - start of intervals based on the GTS2012: Archean [4000 Ma], Paleoproterozoic [2500 Ma], Mesoproterozoic [1600 Ma], Neoproterozoic [1000 Ma], Cambrian [541.0 Ma], Ordovician [485.4 Ma], Silurian [443.8 Ma], Devonian [419.2 Ma], Carboniferous [358.9 Ma], Permian [298.9 Ma]). A) Each individual plot records one of the known 594 alluvial stratigraphic units deposited during this interval. Long-dashed line $=10 \%$; Short-dashed line $=$ 2\%. B) Enlarged plot for the Phanerozoic with LOESS regression line (solid grey line). LOESS was conducted with a smoothing parameter of 0.9. C) Proportion of mudrock corrected for variation in sampling intensity by subsampling. Each individual plot represents the median value 

seen across 100 individual subsampling trials (see supplementary materials for methodology). D)

295 Median, range, upper quartile and lower quartile of mudrock proportion for each interval.

\section{Supplementary Materials}

297 Materials and Methods

298 Table S1 (Database)

299 Figures S1-S15

300 References (38-71)

301 


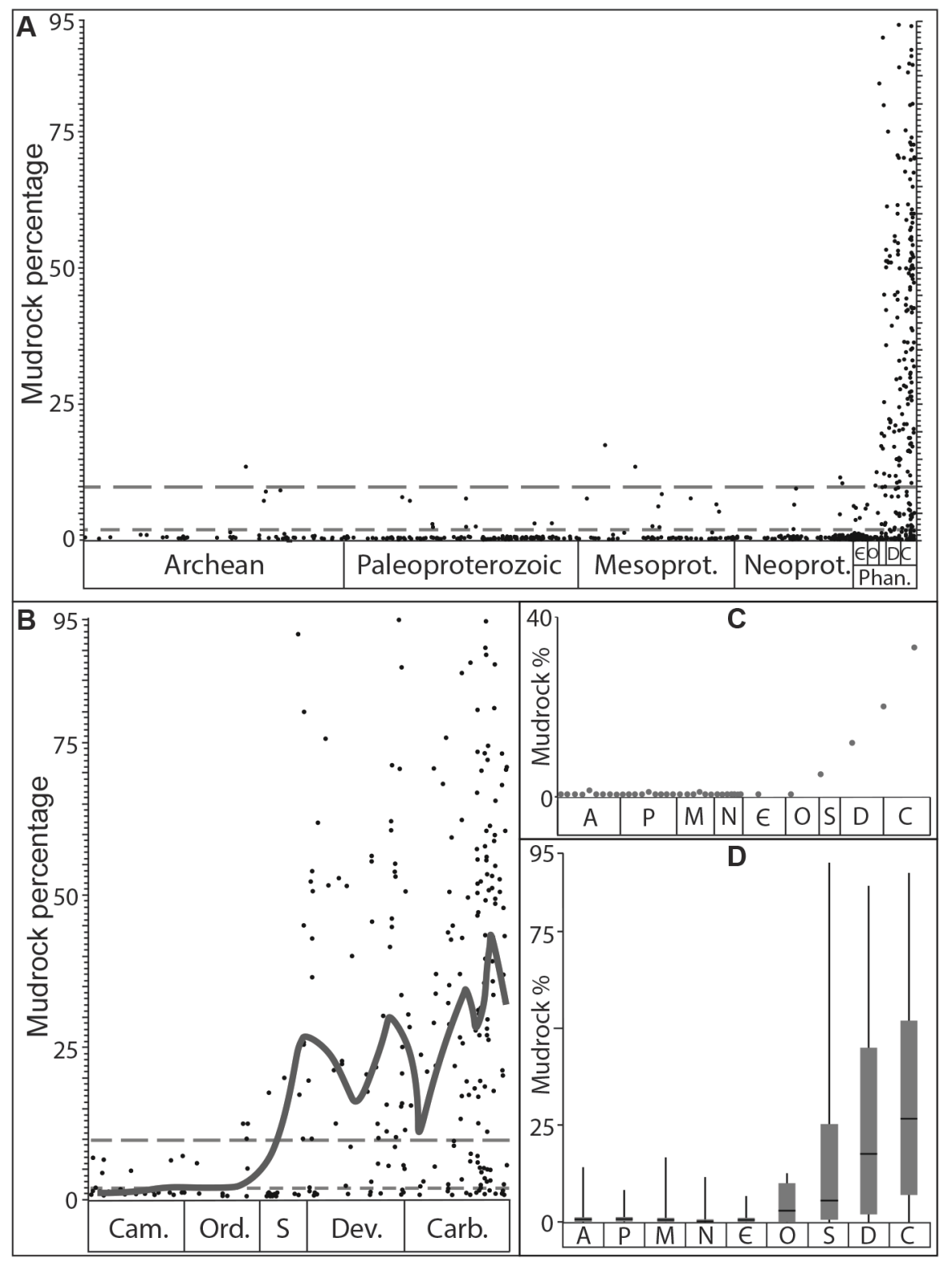




\title{
Science \\ МTAAAS
}

\section{Supplementary Materials for}

\section{Evolution of alluvial mudrock forced by early land plants}

\author{
William J. McMahon, Neil S. Davies \\ *correspondence to: nsd27@cam.ac.uk
}

This PDF file includes:

Materials and Methods

Figures S1-S15

References (38-71)

Other Suplementary Materials for this manuscript includes the following:

Table S1 (Database of alluvial mudrock) 


\section{Materials and Methods}

\subsection{Database construction}

The data presented was quantified from a database of alluvial formations, compiled from a survey of published literature and original fieldwork at 125 sites (Table S1). To the extent that could be ascertained by the authors (from primarily English-language publications), these formations comprise the complete Archean to Carboniferous alluvial record of Earth. The compilation was initiated using the internet search engines ISI Web of Science (38), GeoRef (39), and Google Scholar (40), using the search terms "fluvial" and "alluvial" in conjunction with both extant and outdated, global and regional stratigraphic terms in both British and American English (e.g., "Paleoproterozoic", "Palaeoproterozoic", "Carboniferous", "Pennsylvanian"), with the primary search made in March 2015. The dataset was later expanded utilizing references cited within these results, new publications, and by incorporating conference abstracts, regional guidebooks, geological survey reports, and $\mathrm{PhD}$ and Masters theses where these could be identified or were already known to the present authors. The method has ensured that any unit in the database has previously been interpreted, from its sedimentary character, to represent an alluvial sedimentary deposit. Note that the search was not undertaken on lithological grounds and terms such as 'Sandstone' or 'Quartzite' are only listed in the database where these are local names for lithostratigraphic units (i.e., metasedimentary units were also included in the database, but only if their depositional environment had previously been interpreted; e.g., "60. Baraboo Quartzite").

The survey yielded 1196 original publications of relevance, which were each individually data-mined for information on mudrock proportion. The formations cited in these were grouped or subdivided into the most recently used or formal stratigraphic nomenclature, where known, with particular use made of the online stratigraphic lexicons of the UK (41), USA (42), Canada (43) and Australia (44). For comparability, the ages of the units were translated onto the GTS2012 geological timescale (45) and, when plotting mudrock percentage for a particular formation, the mean age of the formation was used (e.g., "230. Freda Sandstone" has a proposed age of 982-1042 Ma [see Table S1], so was plotted as $1012 \mathrm{Ma})$.

The process yielded 704 individual alluvial formations (see supplementary Mudrock Database), of which 594 contained sufficient data on mudrock content to construct the graphs in Figure 1.

Formations were considered to have an alluvial origin on the sole basis of the interpretation by the authors of original publications (see Section 2.3). To mitigate the problem of previous misinterpretation, the formation datapoints were individually subjected to further scrutiny. Where any given stratigraphic formation was composed of the facies of multiple environments, we refer only to the alluvial facies of that unit.

\subsection{Assessing mudrock abundance}


The abundance of mudrock was assessed by measuring the stratigraphic thickness of the lithology, relative to coarser sediment fractions within each alluvial formation. For published data, where the proportional thickness was explicitly recorded by the original authors this information was used. If the original authors gave a range of mudrock values, the average value was used. In other instances, such data was not noted, but the presentation of stratigraphic logs enabled the proportion to be calculated by our own direct measurement of the thicknesses of different strata. For 110 of the 704 total formations, retrieving any value of mudrock percentage was not possible. For datapoints derived from original fieldwork, the proportion of mudrock was calculated directly at outcrop by the present authors (Fig. S1): although there were instances where mudrock type could not be discerned from field observations.

The abundance estimates are made using stratigraphic thickness because such information is readily retrievable from published data and in the field. The stratigraphic thickness of mudrock refers to the relative proportion of mudrock at a point locality (e.g., as exposed in outcrop or core). It differs from volumetric data, but is more accurate for the present study for the following reasons: 1) While volume is ultimately the desired value which we seek, it cannot be directly measured in the same way as stratigraphic thickness. Volumetric data is estimated, primarily calculated using outcrop data (e.g., the areal extent of a mapped lithologic unit, combined with tectonic dip $(17,46))$. Subsurface variation in mudrock content cannot be addressed using either volume estimates or thickness measurements; however, the latter provides true data in the form of random sampling of points within a volumetric succession (i.e., those parts of the succession which happen to be exposed); 2) Thickness can be directly corrected for tectonic tilt; 3) It is important to note that the values presented are cumulative: that is, without exception in all 704 formations, there was no direct segregation of mudrock and coarser sedimentary lithologies. For example, a 100 metre thick succession with 50\% mudrock would never be 50 metres of sandstone followed by 50 metres of mudrock, but rather alternating and repeating sandstone and mudrock layers on a cm- to m-scale. Resolving such fine detail is only possible through measurement from stratigraphic sections and cannot be achieved using coarser datasets such as geologic maps (The alternating nature of such heterolithic strata also mitigates against issues of suspected preferential erosion of mudrock strata in that lithified mudrock cannot be surgically extracted from between sandstone layers whilst retaining the integrity of a stratigraphic exposure - see later); and 4) Mudrock strata undergo greater postdepositional compaction than coarser sedimentary rocks. However, it is inconsequential that thicknesses of mudrock strata do not reflect original thicknesses of mud accumulation. Strata of Archean to Carboniferous age are all fully lithified, and comparison of the proportion of mudrock strata relative to coarser sediment is an accurate proxy for understanding relative mudrock abundance.

The term 'mudrock' is used here as an umbrella grouping of multiple distinct types of finegrained sediment ( $<62.5 \mu \mathrm{m}$ grains: mudstone, siltstone, claystone, shale). Individual types of mudrock are variably defined based upon grain-size and fissility and are not necessarily mutually exclusive (e.g., a mudrock could be both a shale and a mudstone, or both a shale and a claystone) $(9,47)$. Additionally, the accurate classification of mudrock type is often not possible in hand specimen and requires additional petrographic analyses. 
In the studies used to compile the database, the classification of mudrock type was made to widely different levels of accuracy, depending on the individual scientific remit of any one original publication. As such, mudrock terminology (mudrock, mudstone, siltstone, claystone, shale) is reported here in accordance with the usage of the original authors, and no interpretive grouping of terms was undertaken, in order to mitigate misinterpretation. For this reason, the trends in mudrock proportion as a whole are likely to be more accurate than for individual mudrock types (which may originally have been diagnosed with varying degrees of certainty). Figure S2 shows the datapoints used in Figure 1A, colour-coded as per original rock type descriptions. Although, there was insufficient published data to further subdivide the datapoints (e.g., in terms of clay mineralogy (2)), the figure shows the average proportion of siltstone versus other mudrock types. Siltstones are more readily differentiated in hand specimen, so reports of this lithology were more numerous than for other mudrocks and their trends more amenable to closer scrutiny. Additionally, siltstones have the potential to comprise a sizeable fraction of mechanically-generated fines, so the fact that they show the same trend as other mudrocks, which may have a larger component of chemically-weathered fines, suggests that clay production alone cannot account for the trend, and that there was an element of physical retention that prevented winnowing of fines from continents (48-49). We emphasise that not all siltstones are mechanicallygenerated and not all finer mudrocks are chemically-weathered, so the veracity of this interpretation of the trend is open to more refined investigation.

\subsection{Mitigation against geographic bias}

Geographic bias could skew observed trends if particular paleo-tectonic or -climatic settings were over-represented. However, this is not considered a problem within the dataset. Although North American and European case studies dominate our (predominantly English-language) survey, the survey has global coverage (Fig. S3) and data from every modern continent are represented in the study; North America $(\mathrm{n}=262,37.3 \%)$; Europe $(\mathrm{n}=195,27.7 \%)$; Asia $(\mathrm{n}=65,9.2 \%)$; Africa $(\mathrm{n}=80,11.3 \%)$; Australia $(\mathrm{n}=56,8.0 \%)$; South America $(n=41,5.8 \%)$; Antarctica $(n=5,0.7 \%)$. Additionally, Figure S4 shows that the same trend is apparent even when North American and European datapoints are removed from the plot.

A lack of studies or published data for certain regions (e.g., central Africa) is a natural limitation of the project, but near-global coverage of the existing data mitigates against the likelihood that these regions contain any unique signatures that would skew observed trends if they were available for inclusion. Further, plate tectonic realignment of the continents since the deposition of the different formations means that the paleogeographic spread of datapoints is substantially more global for any given interval than is apparent from the modern geographic spread.

\section{Elimination of hypothesized non-vegetation causes for the trend}

The observed trend, of increasing alluvial mudrock proportion within younger strata, could abductively be explained by (1) syn-depositional basin space controls on mudrock 
accumulation; (2) post-depositional attrition and erosion of older mudrock; (3) misidentification of mudrock-rich alluvial successions in older strata; or (4) tectonic or climatic controls. These four hypotheses have been tested and rejected, for the reasons outlined in the following sections (2.1-2.4).

\subsection{Rejection of basinal causes for the trend}

There is a superficial similarity between the observed decrease in mudrock as a fraction of total alluvial sedimentary rock volume, and the recently quantified decline in total nonmarine sedimentary rock volume with time (17). The superficiality of this trend becomes immediately apparent when our plot is inverted to show the proportion of non-mudrock sedimentary strata in alluvium, and thus shows no positive correlation with total nonmarine sedimentary rock volume (Fig. S5).

As a quantification of vertical stratigraphic proportions, rather than bulk volume, the plot is thus wholly different in nature to plots that consider the aerial coverage of sedimentary strata (i.e., as determined from geological maps) as a proxy for the amount of sedimentary rock for a given interval (17). While intensive (proportion) and extensive (volume) properties of the geological record are not directly comparable, there is a chance that they share a common cause. Studies of non-marine sedimentary rock volume have ascribed an early Palaeozoic increase to major changes in accommodation space on the continents (17). If the proportion of mudrock had the same underlying cause, then it should be expected to mirror the trends seen in total sedimentary rock volume: however, Figure S6 shows that it does not. The proportion of mudrock remains minimal throughout the Precambrian, even during intervals where total rock volume spikes to levels analogous to post-vegetation intervals (e.g., intervals of the alter Neoproterozoic have amounts of rock volume comparable to or greater than at the Silurian-Devonian transition, yet mudrock is significantly more abundant during the latter interval). Furthermore, the onset of increasing sedimentary rock volume is considerably delayed from the onset of the mudrock rise (Fig. S6). The amount of mudrock as a proportion exhibits a diminishment in the latest Carboniferous (Fig. S6C), which partly mirrors the rock volume trend: suggesting that accommodation space could potentially play a role in mudrock content during this interval, but that it is clearly a subservient control to that which triggered the onset of the mudrock rise (Fig. S6B).

Finally, the argument that limited basin extent discourages mudrock accumulation in the alluvial realm, and that this explains the observed trend, relies on a model that all fluvial systems bypass sediment during low accommodation conditions. The veracity of this contention requires: 1) Persistent and global low accommodation for the c. 3.0 Ga duration of the Archean through to at least the Ordovician; and 2) The assumption that the net sedimentary product of all of the world's rivers (at any given interval of Earth history) is analogous to that seen in an individual, distributive (50), fluvial system at the present day. The first of these requirements alone is considered unlikely enough that accommodation space cannot be a cause of the trend (discussed further in Section 2.4.). The likelihood of the second contention cannot currently be assessed because of the limited data that exists to support it, but it should be noted that not all alluvium preserved in the rock record is the product of distributive fluvial systems (51) and that the argument that low accommodation 
means less mudrock need not apply to those datapoints which record the alluvium of tributive and other systems.

\subsection{Rejection of attrition and erosion as a cause for the trend}

The amount of preserved non-marine sedimentary rock generally diminishes further back in geological time $(17,52)$, and the stratigraphic record is biased to sediment that accumulated in basins (53), but preservation bias cannot explain the observed trends. There is no logical reason why bulk post-depositional attrition would preferentially affect mudrock strata, especially within heterolithic successions, because controls such as out-ofbasin erosion and tectonic recycling should affect all lithologies with an equal likelihood. In respect to such attrition, while the deep time mudrock record is undisputedly incomplete, the record of coarser-grained sedimentary rocks should be equally incomplete; rendering a null effect on the inclusive values discussed here. It is therefore highly unlikely that random attrition led to the observed trend (i.e., no units between 3500-411 Ma containing $>15 \%$ mudrock).

We formally evaluate this likelihood using cumulative frequency plots. We have constructed cumulative frequency vs. time plots by cumulatively summing the mudrock fraction of each sample and dividing by the total mudrock fraction (Fig. S7, Fig. S8); in this way, the cumulative frequency is 0 before the first sample at $3.5 \mathrm{Ga}$ and is 1 by the end of the Carboniferous, with the structure both reflecting how samples are distributed in time and their mudrock content. By then constructing synthetic cumulative frequency plots, based on the random sampling of the 400-300 Ma sample population (the most well represented $100 \mathrm{Myr}$ interval), we can test the observed data distribution against null hypotheses.

Two null hypotheses were compared with the actual distribution of data, with synthetic data calculated 100 times for each, following the Monte Carlo Method (54): 1) A scenario where mudrock percentage follows a normal distribution, using mean and standard deviation values calculated from the entire dataset (Precambrian and Phanerozoic) (Fig. S7A); and 2) A scenario where mudrock percentage follows a normal distribution, using mean and standard deviation values calculated from Phanerozoic values only (Figure S7B, Figure S8). The first test illustrates the likelihood of the actual distribution of data arising by chance. By being restricted to the well-populated key interval of change, the second test assesses the likelihood of progressively decreased sampling deeper into geological time having affected the observed mudrock distribution. None of the synthetic profiles presented in Figure S7 and Figure S8 demonstrate either: 1) Very small cumulative mudrock values $(<0.075)$ between $3500 \mathrm{Ma}-500 \mathrm{Ma}$; or 2) A sharp increase in cumulative mudrock values timed approximately with the first appearance of land plants. This demonstrates that the sharp increase in post-Devonian mudrock fraction is not an attrition artefact, as no synthetic distributions reproduce the trend.

To quantitatively test similarity of the synthetic and real cumulative frequency distributions the Kolmogorov-Smirnov test was used. The Kolmogorov-Smirnov statistic, d(K-S) (the maximum in separation between cumulative frequency curves), assesses cumulative distributions for similarity (55), with smaller $\mathrm{d}(\mathrm{K}-\mathrm{S})$ values indicating more similar distributions. Both scenarios returned large d(k-s) values (scenario $1=0.541933$ [Fig. 
S7A], scenario $2=0.540084$ [Fig. S7B]), thus emphasizing the dissimilarity between the actual and synthetic distributions. Furthermore, $\mathrm{d}(\mathrm{k}-\mathrm{s})$ is far greater than the critical value in both instances (dcrit $=0.068514, \alpha=0.01$ ), indicating that the null hypotheses can be rejected with a confidence level significantly greater than $99.9 \%$. The $\mathrm{d}(\mathrm{k}-\mathrm{s})$ value for the Phanerozoic only plot (Fig. S8) also exceeded dcrit ( 0.214981 and 0.097937 respectively), further emphasizing the validity of the observed mudrock distribution.

The erodibility of mudrock is also ruled out as an explanation. Mudrocks may be more susceptible to modern erosion and weathering from outcrop than coarser-grained sedimentary rocks, due to internal fissility and mechanical weaknesses. However, this study compares rock with rock: post-lithification, there is no reason why a Precambrian mudrock should be any more or less susceptible to modern erosion than a Phanerozoic mudrock and each dataset should be equally prone to this depleting effect. Precambrian mudrocks, being older and therefore subject to a potentially greater array of burial/heating events, may in fact be suspected to be less prone to erosion as metasedimentary mudrocks are often mechanically stronger than 'fresh' mudrock. Additionally, the heterolithic and interbedded nature of mudrock and sandstone means that it is not possible to surgically remove only mudrock, despite its greater erodibility, even during those syn-depositional erosion events that excise large parts of the stratigraphic record (52).

Where exposed on Earth's surface today, sandstone-dominated successions tend to form cliffs (more amenable to geological investigation), whereas erodible mud-rich successions are more likely to be hidden by soil and talus. Thus, there is an inherent observation bias in favour of sandstone-dominated strata in outcrop investigation. However, this observation bias is again uniform across the entire geological record (certainly so for fully lithified ancient strata of Precambrian through Carboniferous age) and so cannot detract from the validity of the mudrock upsurge presented in Figure 1.

\subsection{Rejection of observer bias as a cause for the trend}

The holistic approach that has been employed negates, to the maximum extent possible, issues of sampling bias. As it encompasses all possible datapoints, the trend accurately represents what is preserved in the global rock record, as is currently known. Subsampling of the data was used to remove any concern that uneven sampling for different time intervals may have biased the data (Fig. 1C). A random subset of the available dataset is drawn until each interval, called a sampling bin, includes the same estimated number of datapoints (56). The dataset was split into 30 sampling bins separated at 100 million year intervals from 3500-700 Ma, and then at 40 million year intervals from 699-299 million years ago. These intervals were chosen as they provide great enough temporal resolution to ensure each key interval in the Phanerozoic is represented, whilst ensuring each sampling bin contains enough original data on mudrock proportion to randomly draw from. 125 data points were randomly drawn from the original data for each sampling bin. This process was repeated 100 times to obtain averages. In figure 1C, each datapoint represents the median value seen across the 100 individual subsampling trials. In addition to correcting for variation in sampling intensity, subsampling enables the order of magnitude increase in mudrock proportion for each key interval to be calculated (see main text). 
An alternative method for validating the global mudrock abundance time series is to use a hypergeometric distribution based on the null hypothesis that the spread of datapoints from the interval preceding root evolution was originally the same as the post-root interval (411$300 \mathrm{Ma}$ ), and that the observation of a mudrock-deficient older alluvial record is a bias effect of random sampling. Hypergeometric distributions perform sampling without replacement, and therefore can determine the likelihood of drawing a particular set of samples from an underlying population. In the case of our global record of mudrock abundances, for the null hypothesis to be true requires that 366 draws (the number of observed datapoints pre-dating root evolution (20)) from the true distribution are made. Assuming that the population of the 411-300 Ma bin is reflective of the 'true' distribution, the 28 preceding bins (each of 111 Ma duration) can be scaled to contain a population of 6200 samples, of which 3565 should contain $>15 \%$ mudrock. The probability that none of these 3565 hypothetical samples were drawn in 366 draws from the hypothetical pool of 6200 (due to sampling) is less than $30^{-164}$. The observed mudrock proportion trend is thus statistically sound.

The misidentification of mudrock-rich alluvial strata as being of a marine origin in older units may reasonably be expected to have biased the observed trend. Alluvium may be identified through the physical sedimentary characteristics of a rock unit, including palaeocurrent variance and sedimentary architecture (57-58). Notwithstanding this, there are instances in which it may be problematic to conclusively distinguish alluvial strata from marine strata, particularly in the Precambrian. We cannot account for instances where previous authors have misinterpreted strata based on limited and non-diagnostic criteria (e.g., using an abundance of cross-bedded sandstones to declare a unit 'fluvial'). The strength of the observed trend would require that the misidentification of alluvial strata was an endemic problem to a significant fraction of the studies of 383 pre-Ordovician units, carried out over the last c. 70 years, as cited in the database, but could be a source of uncontrolled bias. However, there are five reasons why the effects of any such bias may be minimal: 1) Our own investigations of $18 \%$ of the units $(n=125)$ suggest that the majority of interpretations of an alluvial origin are accurate. Ground-truthing of these units was undertaken using standard sedimentary geological field techniques (e.g., stratigraphic logging, architectural analysis). The trend from Figure 1 remains apparent when the plot is reconstructed using only those formations which we have ground-truthed (Fig. S9). 2) The Ordovician-Devonian upsurge in preserved mudrock post-dates the evolution of abundant marine shelly fossils and bioturbation in the Cambrian. For this latter interval, paleontological and ichnological data reduce the risk of inaccurately discerning marine and alluvial strata and yet alluvial mudrock remains minimal, and analogous to preceded Precambrian periods, during this interval (Fig. 1B); 3) $52 \%$ of the formations in the database are known from multiple papers by different authors: the likelihood of multiple sets of authors making the same erroneous conclusion is more limited than for those studies that involve only one previous study; 4) The majority of studies were undertaken specifically as sedimentary geology studies, with the express intent of understanding paleoenvironment. Researchers within this field of expertise are less likely to have made simplistic assumptions (e.g., trough cross-bedding $=$ fluvial) than non-specialist researchers, as multiple lines of sedimentological evidence exist to identify marine strata, with or without the presence of paleontological information (i.e., through an assessment of the balance and combination of sedimentary characteristics including paleocurrent 
variance and sedimentary architecture (57-60) (Fig. S10)); and 5) The issue of misidentification would only negate the observed trend if certain (mud-rich) pre-vegetation fluvial strata have been misidentified as marine and therefore missed during our data collection: if the converse is true, whereby some marine strata have been interpreted as fluvial, this makes no material difference to the data set - it might contain some 'false' datapoints (most likely in older strata lacking fossil evidence), but does not affect the trend. In the authors direct experience of fieldwork and study of $>20$ pre-vegetation successions previously described as marine in origin, we have previously encountered no instances where strata exhibiting diagnostic fluvial characteristics have previously been misidentified as marine.

\subsection{Rejection of cyclic allogenic forces as a cause for the trend}

The statistical tests used to mitigate against attrition as a cause for the trend (Section 2.2) suggest that the trend marks a stratigraphically unidirectional shift of increasing alluvial mudrock, which is thus not readily explainable as having been forced by those cyclic geological phenomena that were continually in operation prior to the onset of the trend (Fig. S11).

Modern-style plate tectonics are known to have been continuously active since at least $1830 \mathrm{Ma}$ (61), and sea-level and climate fluctuations were continually operational across the entire $3200 \mathrm{Ma}$ study interval. None of these can account for the stratigraphically unidirectional nature of the onset of the observed trend. Even accounting for the high sealevels and orogenic basins in the Devonian (which may have been more amenable to mudrock accumulation), the absence of earlier mudrock spikes suggest that a unidirectional change to the Earth system is required in addition to any tectonic/climate/sea-level controls (12). Numerous Precambrian supercontinents are known (13), as well as at least 16 preOrdovician orogenies (14), which should be expected to have contributed to earlier spikes, yet our directly observed data (Section 2.3) and statistical tests (Section 2.2) demonstrate that it is highly unlikely that such spikes previously existed but were later eroded.

Whilst cyclical phenomena undoubtedly have an effect on the preserved global alluvial record, the variation in mudrock abundance that these induce can only be directly compared in similarly aged intervals (i.e., not between pre- and post-vegetation evolution intervals). For example, in rocks of a common age, before and after the Ordovician, alluvial mudrock is more abundant in strata deposited adjacent to active orogenic belts than in strata deposited away from active orogenies. However, mudrock deposited adjacent to active orogenic belts prior to the evolution of land plants is significantly less abundant than mudrock deposited away from orogenies after the evolution of land plants (Fig. S12). Climatically, there is little discernible correlation between global alluvial mudrock proportion and the presence or absence of polar glaciations (Fig. S13), yet both glacial and non-glacial intervals are markedly more mud-rich during post-vegetation icehouse conditions (e.g., the late Carboniferous) than they are during pre-vegetation icehouse conditions (e.g., the Cryogenian).

2.5. The timing of the greening of the continents and the onset of increased alluvial mudrock abundance 
The unidirectional onset, and progressive nature, of the increase in mudrock abundance does show strong correlation with the fossil plant record (18-20) (Fig. S11B). The studied interval can be divided into three parts. 1) Pre-vegetation. The average proportion of mudrock in alluvial successions is $1.3 \%$ across all Archean to Early Ordovician formations $(n=348)$, and only $11.2 \%$ of the formations contain greater than $2 \%$ mudrock strata. 2$)$ Primitive vegetation. The average proportion of mudrock in alluvial successions is $15.4 \%$ for Middle Ordovician to Silurian formations $(n=30)$, post-dating the evolution of the earliest land plants (19), and $53.0 \%$ of these formations contain greater than $2 \%$ mudrock. 3) Post-rooting. The average proportion of mudrock in alluvial successions is $29.9 \%$ for formations deposited after the Early Devonian evolution of rooting (20) $(n=216)$, where $78.6 \%$ of units contain greater than $2 \%$ mudrock, and $27.9 \%$ of alluvial units are dominated by mudrock (50-95\% proportion) over coarser-grained sedimentary strata. With current knowledge, the only primary unidirectional global change associated with the two accelerations of alluvial mudrock abundance (Late Ordovician and Devonian) is vegetation evolution (the first land plants and rooting, respectively). We emphasise that this correlation is made with the tangible plant fossil record. As noted by other researchers (18), there presently exist a multitude of hypotheses regarding the timing of land plant colonization of the continents, made using secondary or derived datasets. For example: paleoweathering surfaces have been used to suggest limited greening of the continents in the Ordovician and Silurian (62); clay minerals have been used to suggest a late Precambrian greening of the continents (30); oxygen isotope signals in marine carbonates, and numerical modelling, have been used to suggest Ordovician greening (21); weathering models based on modern plant weathering suggest major Devonian greening (63) (enigmatically preceding the Carboniferous expansion of forests (18)); and molecular clock data postulate a minimum Cambrian origin for land plants (64). Clearly, all of these hypotheses are mutually-exclusive (18), and a fuller understanding of the timing of the greening of the continents requires more than one derived source of interpreted data.

We note that (1) our observations of mudrock increase are closely linked to the undisputed land plant fossil record, (2) cannot be reasonably explained by the most likely alternative hypotheses considered (Sections 2.1-2.4.) and (3) that multiple mechanisms, as seen in modern vegetation, are known to promote mud production and deposition, and that these were absent from the Earth surface prior to Palaeozoic evolutionary innovations. In light of these factors, it is reasonable to infer plant-related causes as the best explanation for the outcome preserved in the global rock record (i.e., a shift in mudrock abundance throughout the Palaeozoic; see discussion in main text). The tangible shift in the character of the alluvial mudrock record may thus be of potential use in the calibration of other derived estimates of the greening of the continents.

Cumulative mudrock proportions binned into 100 Myr intervals visually demonstrate how the increase in mudrock proportion on land is broadly coeval with the paleobotanic record of land plant evolution, with intervals post-dating the first plant fossils showing overall trends closer to a normal distribution than those pre-dating the first plant fossils (Fig. S14). Similarly, Figure S15 illustrates the abrupt increase in the frequency of alluvial formations containing $>2 \%$ mudrock percentage after the evolution of land plants, as evidenced in the fossil record. 
An alternative hypothesis may be entertained in which the onset of the mudrock trend is due to an external trigger not known or not thought about in the preceding sections, and that land plants actually evolved in response to the increase of mud on the continents. In other words, that their evolution was encouraged by their active exploitation of continents on which sediment and water were more efficiently trapped. We suggest that this hypothesis is unlikely because: 1) to our knowledge, there are few unidirectional changes to the Earth system that have not been considered as a potential trigger; and 2) if floral terrestrialization had previously been impeded by unfavourable physical landscape conditions, it would be expected that plant-like photosynthetic terrestrial organisms underwent a polyphyletic radiation once the ideal conditions had been met. However, the monophyly of land plants (65) attests against this, instead suggesting that the limiting factors for land plant colonization were intrinsic (i.e. the acquisition of novel developmental pathways involved in embryogenesis or organogenesis).

\section{Discussion of pre-Ordovician anomalies}

The figured plots show a few anomalous instances of high mudrock content within older strata. In particular, only 5 pre-Middle Ordovician successions contain $>10 \%$ mudrock. These anomalies may be genuine instances of high mud content in alluvial systems and so are included in our plots. However, as seen in Figure 1C, isolated maximum reported mudrock values for a given interval may skew the data, when compared with the median and mean values for pre-Ordovician intervals. For this reason, we specifically address the 5 pre-vegetation, high-mudrock, anomalies below. We emphasise that a similar survey of all of the datapoints used would likely reveal a handful of other instances in which the reported mudrock values may be equally problematic, but as random checking of potentially erroneous datapoints has shown that they are unlikely to be so numerous to detract from the principal result of our analysis, we do not attempt to scrutinize the remaining 589 datapoints (shown in Figure 1) here.

Anomaly 1: Neoarchean Renosterspruit Sandstone (3000-2800 Ma), South Africa, ("Shale" 14\%). A braided alluvial depositional environment was suggested based on the interpretation of planar cross-bedded sandstones as accreting transverse bars (66). Mudrock occurs in beds $<1.5 \mathrm{~m}$-thick and the proportional value was calculated from a 25 $\mathrm{m}$ thick measured stratigraphic section presented in the original publication (66). However, it is unclear whether this illustrated section is typical of the entire $120 \mathrm{~m}$-thick formation.

Anomaly 2: Mesoproterozoic Kasama Fm (1434 Ma), Zambia ("Mudstone" 17\%). Unfossiliferous cross-bedded sandstones and conglomerates have been described as channel bar deposits, and associated massive mudstones are described as floodplain and floodbasin deposits, but with no explanation detailed for these interpretations (67-68). It was only possible to approximate mudrock proportion from 6 x 1:10,000 scale logs.

Anomaly 3: Mesoproterozoic Outan Island Formation (1400 Ma), Canada (Mudrock ["Shale" and "Siltstone"] 14\%). Alternating successions of massive and cross-stratified medium grained sandstones, minor conglomerates and thinly interlaminated mudstones, siltstones and fine-medium grained sandstones have been interpreted as channel and floodplain assemblages respectively (69). The formation is known from core records only, 
lacking stratigraphic architectural data. As such, the environmental interpretation may not be as robust as other case studies, while mudrock proportion is likely to be more accurate.

Anomaly 4: Neoproterozoic Fatira El Zarqa Sequence (600-585 Ma), Egypt ("Mudstone" $12 \%)$. Horizontally laminated mudstones (1-3 m thick) and fine-medium grained sandstones have been interpreted as overbank and "flood sheet" deposits based solely upon their association with each other (70). Mudrock value was calculated from a published, measured $30 \mathrm{~m}$ stratigraphic section, but no published data is available on the formation thickness or how representative the presented stratigraphic section is of the predominant facies.

Anomaly 5: Ediacaran-Cambrian Seival Formation (566-535.2 Ma), Brazil (Mudrock ["Mudstone" and "Siltstone"] 11\%). Unfossiliferous cross-bedded sandstones and conglomerates, and associated laminated siltstones, have been described as recording fluvial channels and overbank deposits floodplain deposits based on their lithology (71). Mudrock value was calculated from 7 illustrated stratigraphic logs, totalling 66 metres of section, but is unclear how many of these logs are from the same stratigraphic horizon, or how representative they are of the formations total 800 metre thickness. 

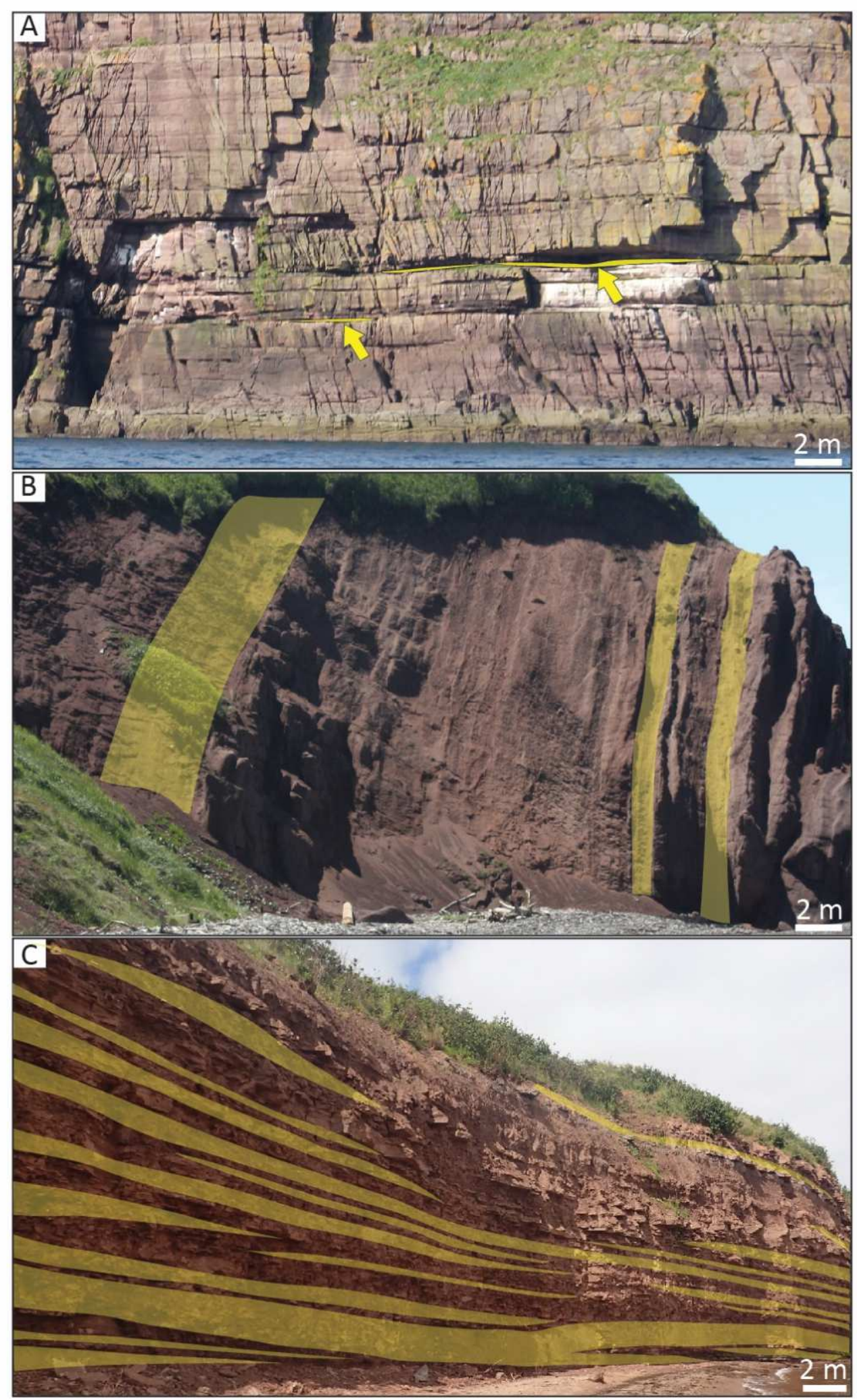


\section{Fig. S1.}

Outcrop extent of mudrock (highlighted yellow) in representative alluvial formations, shown at same scale. A) Neoproterozoic Applecross Formation, Scotland. Formation average mudrock $=\langle 1 \%$; Global average pre-vegetation mudrock $=1.3 \%$. B) Late Ordovician Misty Point Formation, Newfoundland, Canada. Formation average mudrock $=13 \%$; Global average primitive vegetation mudrock $=15.4 \%$; C) Late Carboniferous Cape John Formation, Nova Scotia, Canada. Formation average mudrock $=36 \%$; Global average post-rooting mudrock $=29.9 \%$. 


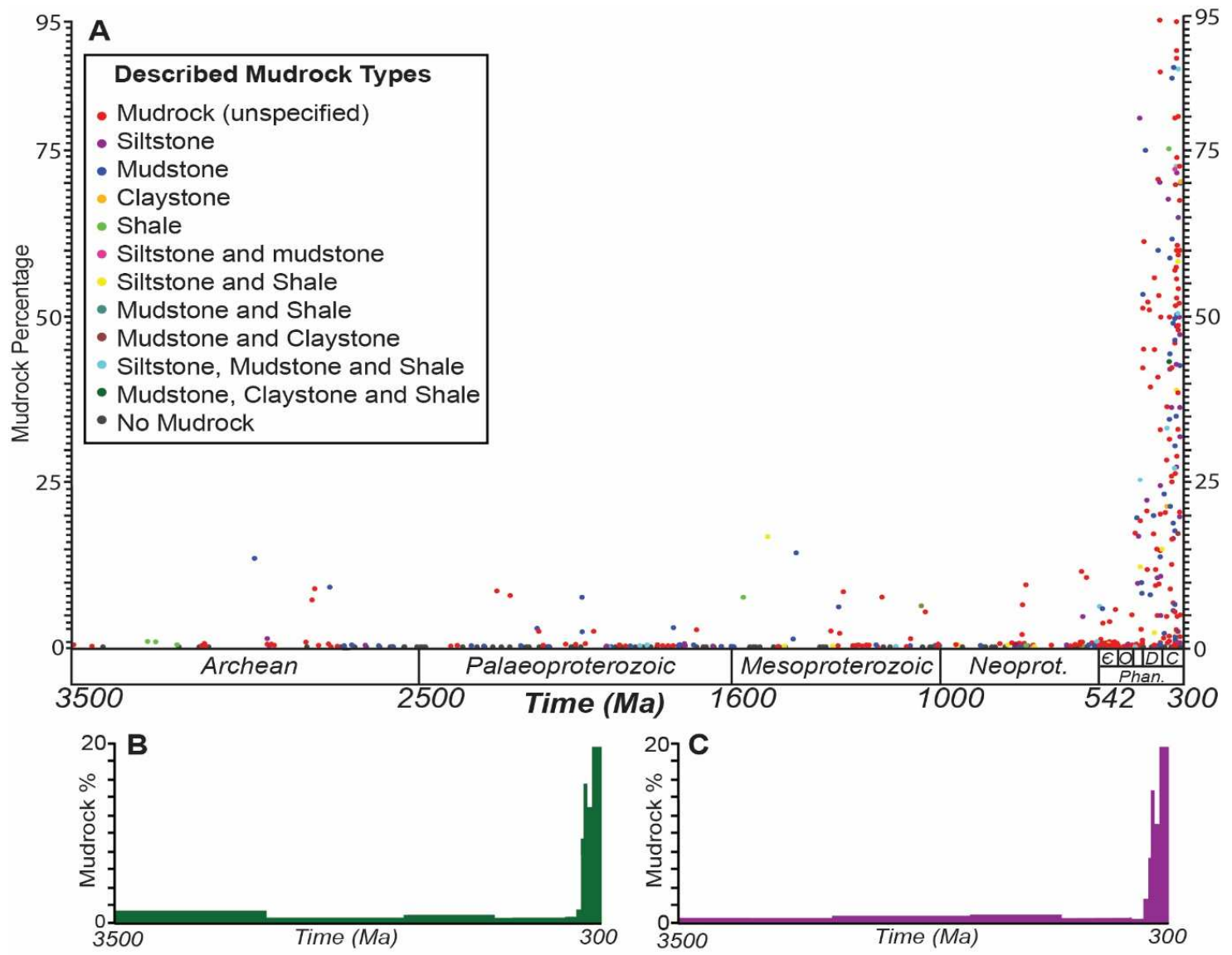

Fig. S2

A) Proportion of mudrock (differentiated by type) within alluvial successions of Archean to Carboniferous age. Each individual plot records one of the known 594 alluvial stratigraphic units deposited during this interval; B) Average plot of mudstone, claystone and shale calculated for each geological Eon (Archean), Era (Palaeoproterozoic to Neoproterozoic) and vegetation stage (4) (Cambrian to Carboniferous); C) Average plot of siltstone calculated for each geological Eon (Archean), Era (Palaeoproterozoic to Neoproterozoic) and vegetation stage (4) (Cambrian to Carboniferous). 


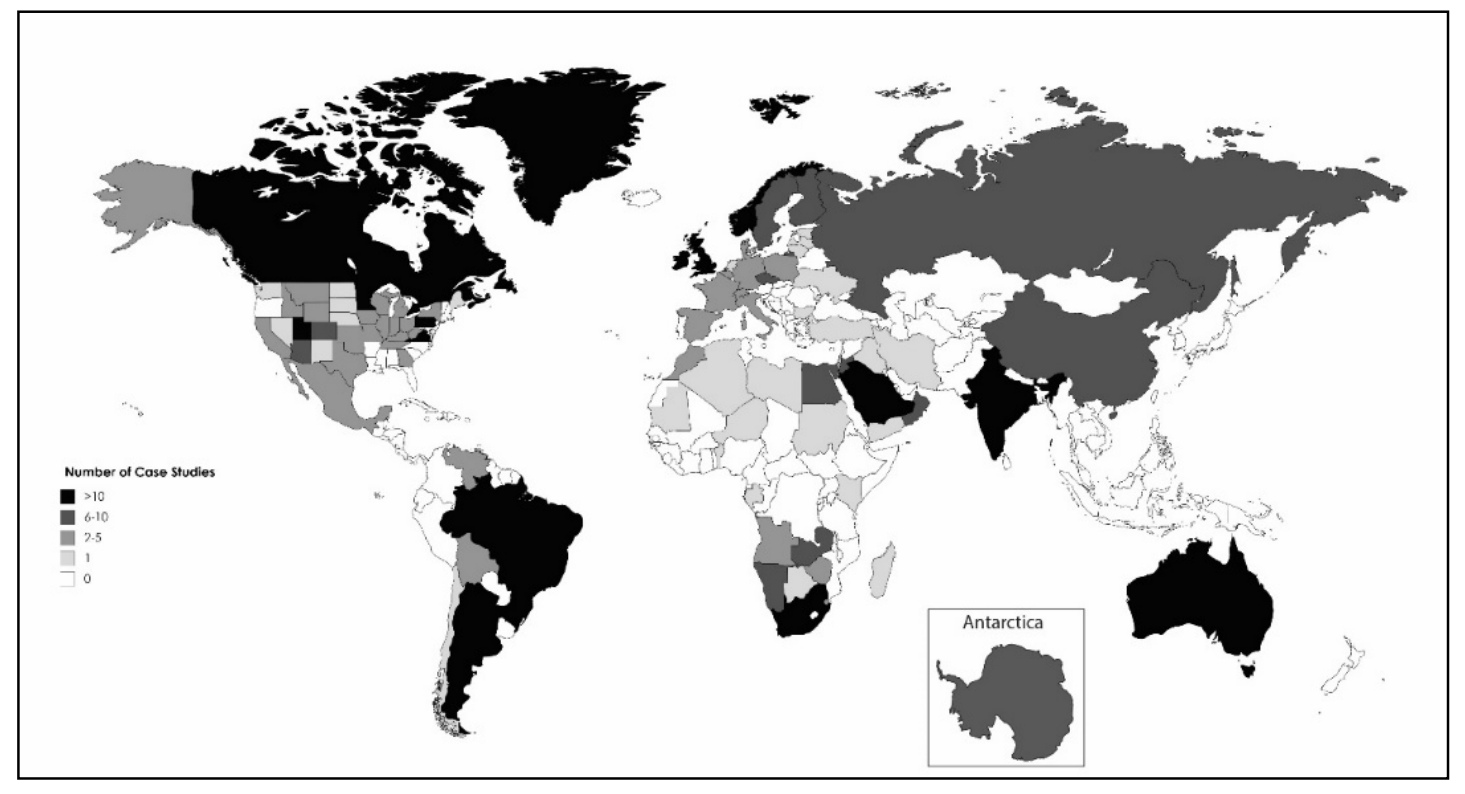


Fig. S3

Geographic distribution of case studies in supplementary Mudrock Database. 


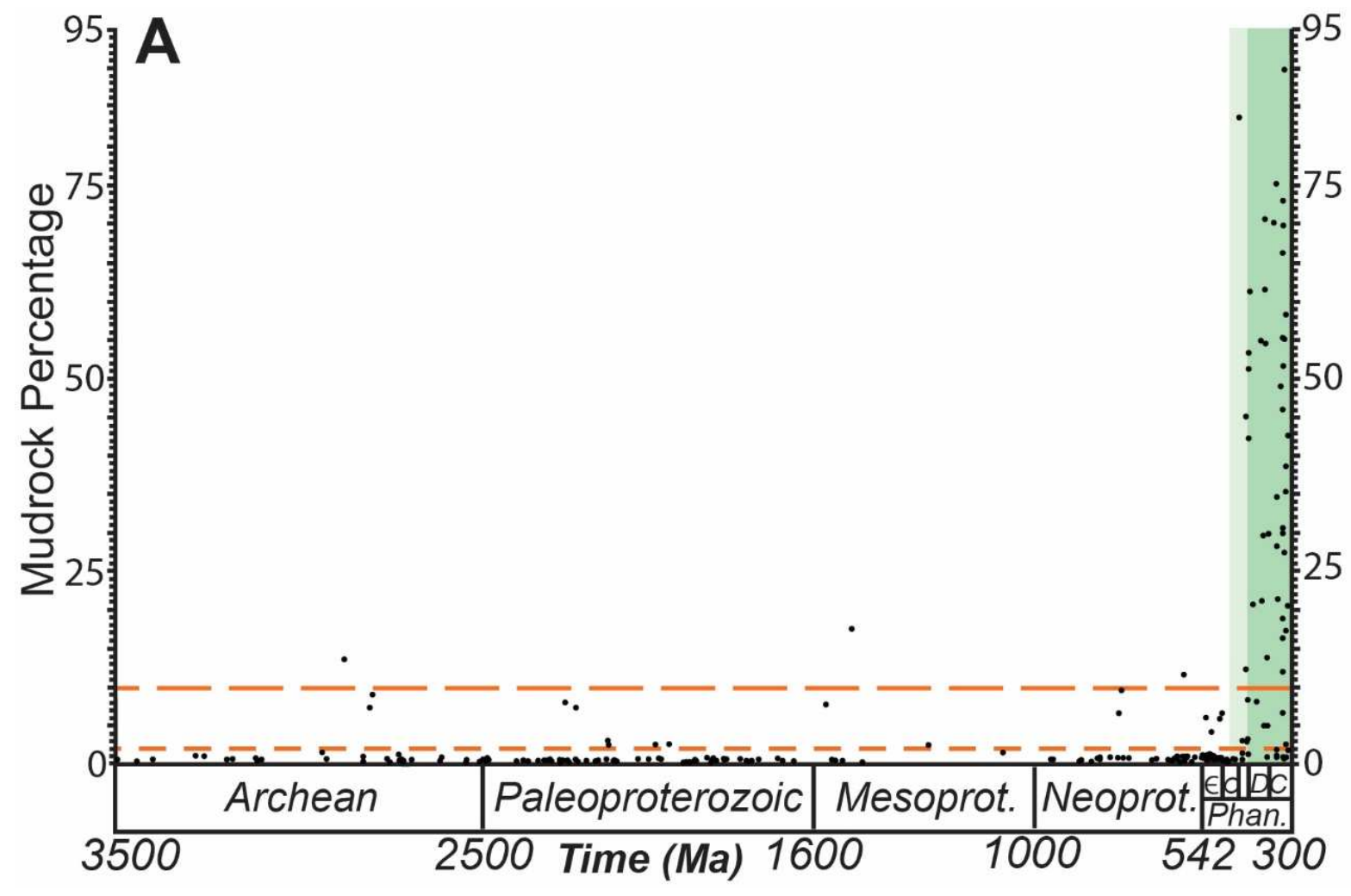

Fig. S4

Proportion of mudrock within 207 alluvial successions of Archean to Carboniferous age (North American and European case studies omitted). Each individual plot records one of the known alluvial stratigraphic units deposited during this interval. Data plotted against paleobotanic evolutionary events (see Figure S11B). 


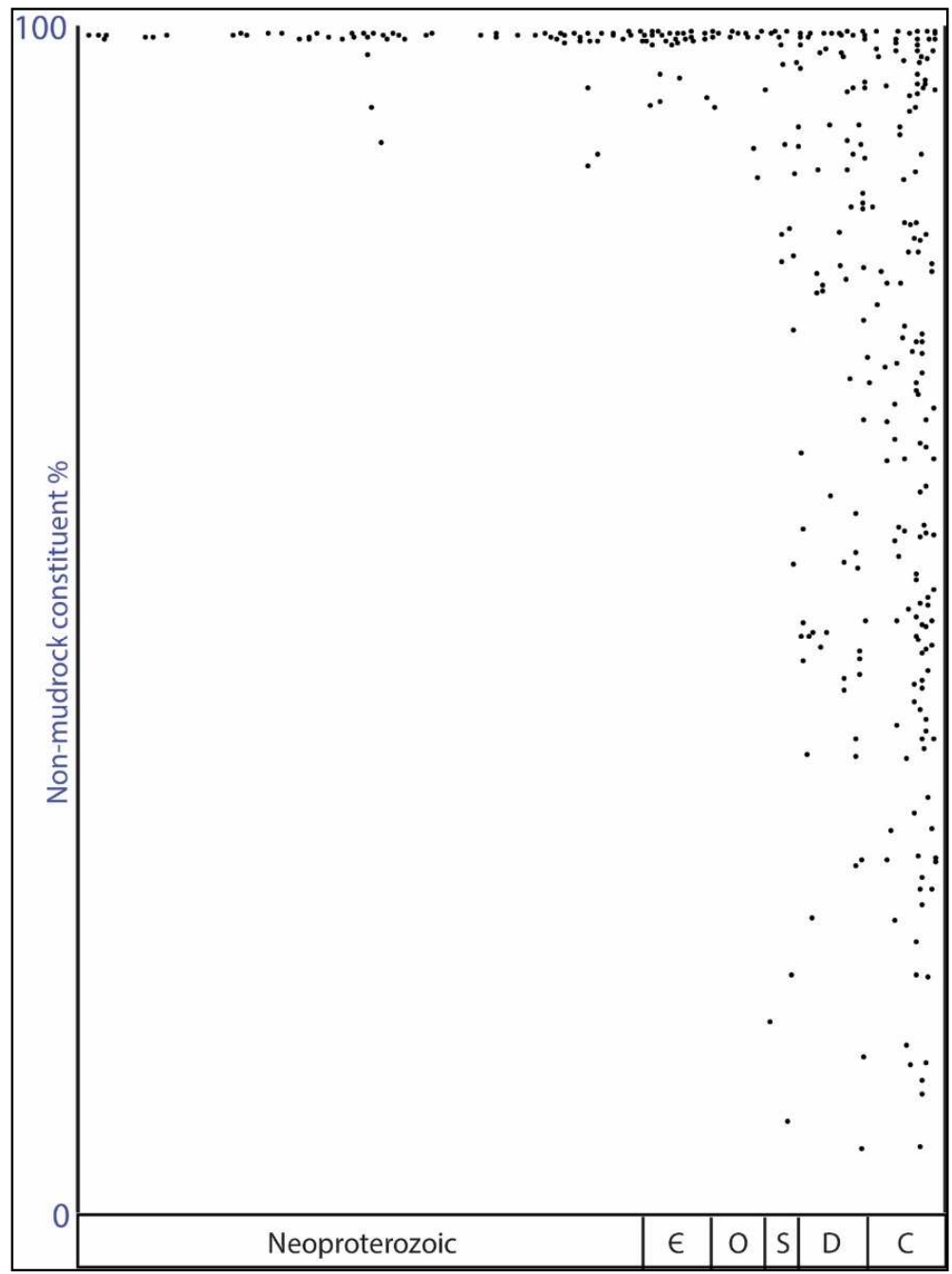

Fig. S5

Proportion of non-mudrock sedimentary strata within alluvial successions of Neoproterozoic to Carboniferous age. Each individual plot records one of the known 367 alluvial stratigraphic units deposited during this interval. 


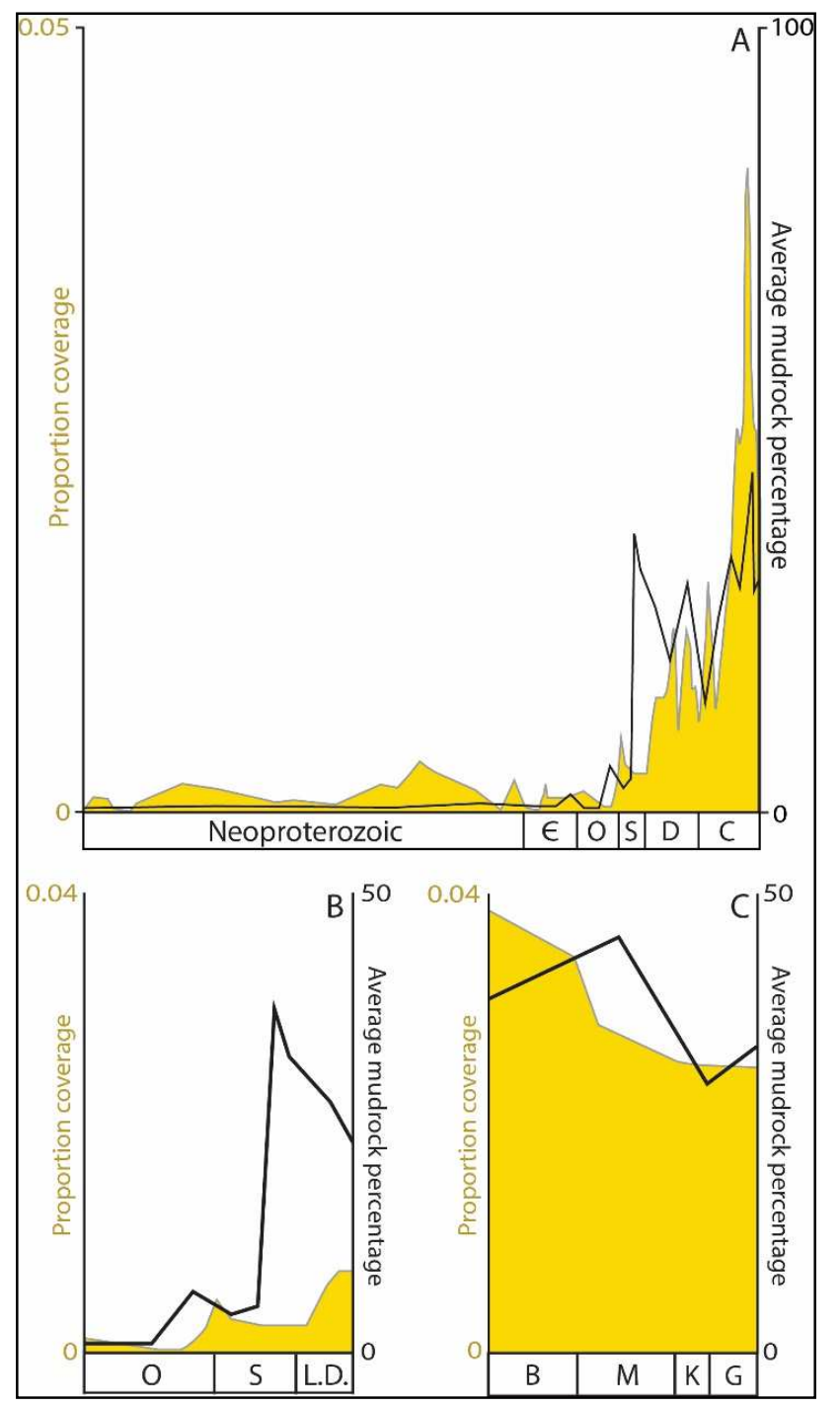

Fig. S6

Black line: Average mudrock percentage within alluvial successions. Using the mudrock data compiled in the database, mudrock average is shown by Period (Neoproterozoic (Tonian, Cryogenian, Ediacaran)), Epoch (Cambrian (Terreneuvian, Stage 2, Stage 3, Furongian), Ordovician (Lower, Middle, Upper), Silurian (Llandovery, Wenlock, Ludlow, Pridoli) and Devonian (Lower, Middle, Upper)) and Stage (Carboniferous (Tournaisian, Visean, Serpukhovian, Bashkirian, Moscovian, Kasimovian, Gzhelian)) (44). Non-marine sedimentary rock volume in yellow (17). 

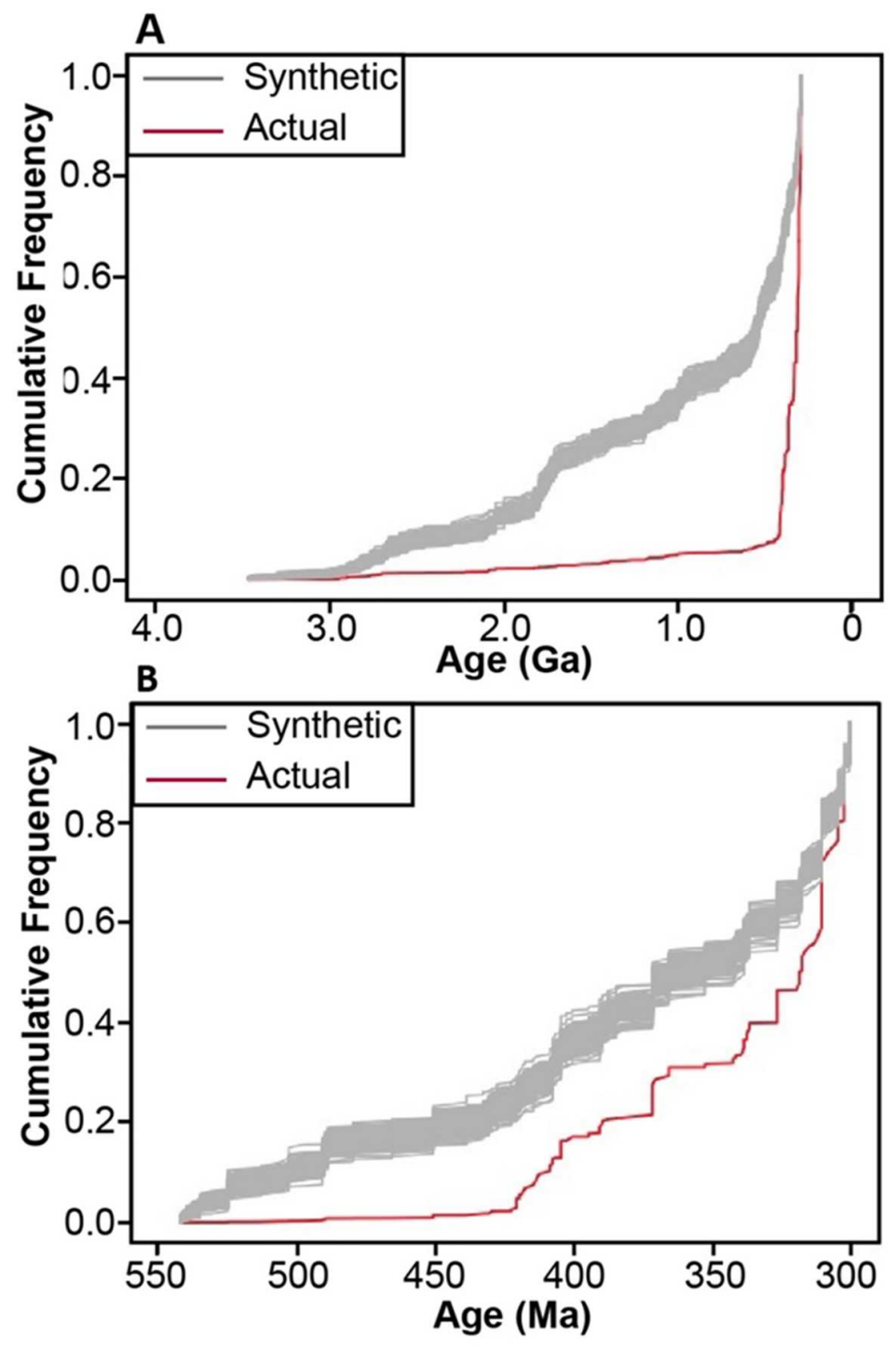

Fig. S7

Cumulative frequency plots comparing the actual distribution of data (red line), with synthetic data $(\mathrm{n}=100)$ (grey lines) assuming the null hypothesis that mudrock distribution follows a normal distribution. A) Using the mean and standard deviation values of the entire database (Precambrian and Phanerozoic). B) Using the mean and standard deviation values of the Phanerozoic only. 


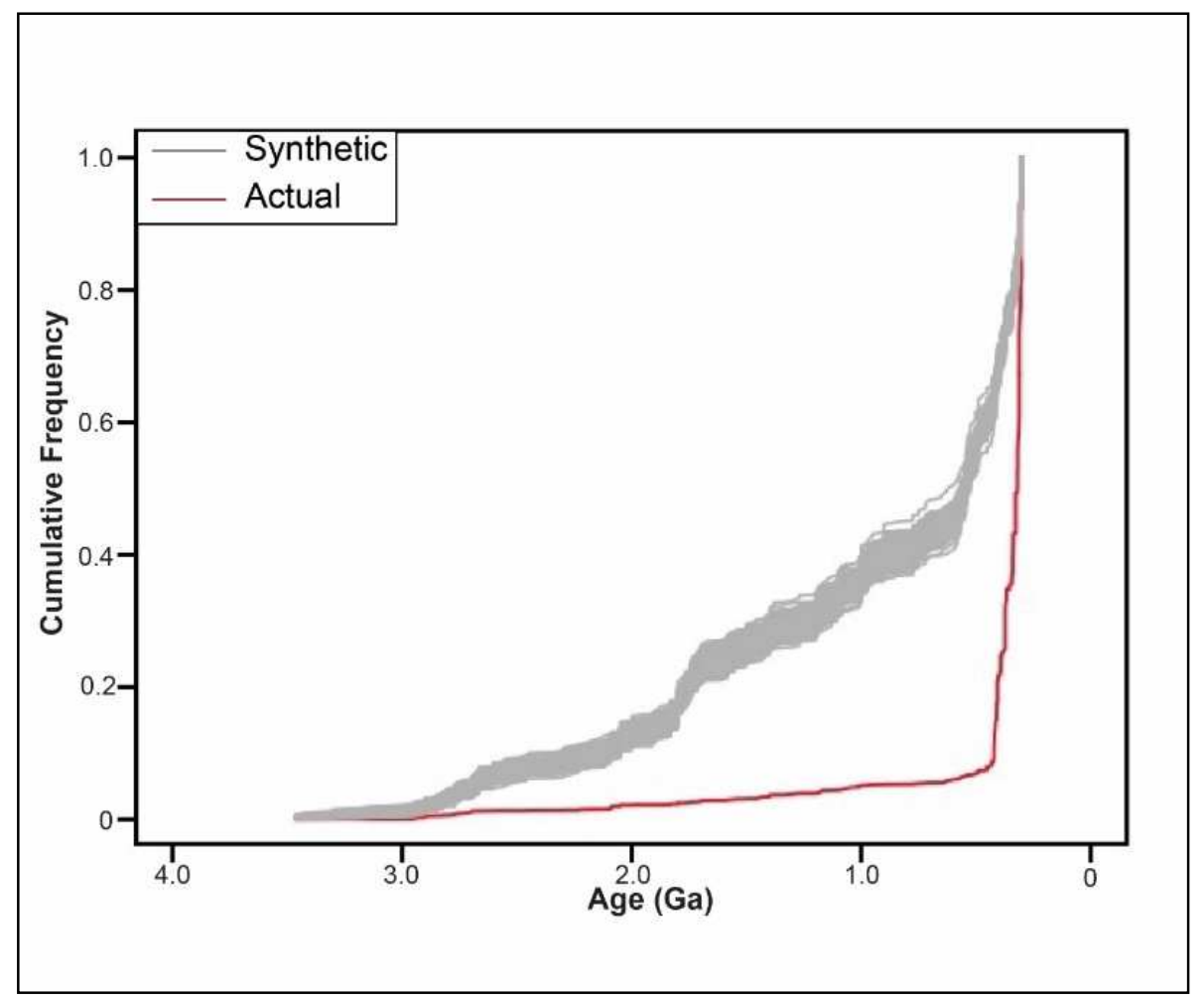

Fig. S8

Cumulative frequency plot comparing the actual distribution of data, with synthetic data $(\mathrm{n}=100)$, assuming the null hypothesis that mudrock distribution follows a normal distribution across 3500-298.9 Ma (mean and standard deviation values of Phanerozoic case studies). 


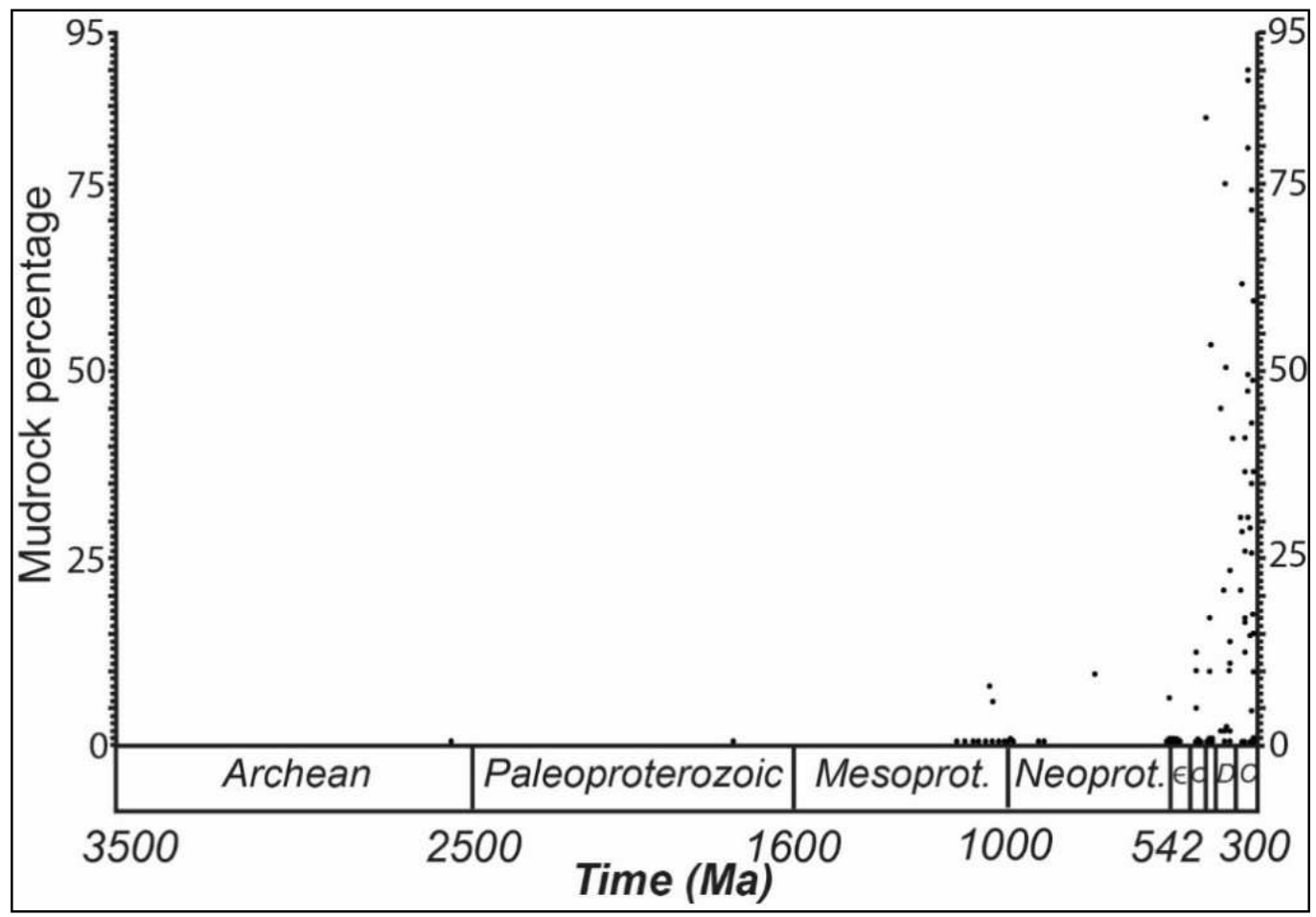

Fig. S9

Proportion of mudrock within 125 directly-measured alluvial successions of Archean to Carboniferous age. 


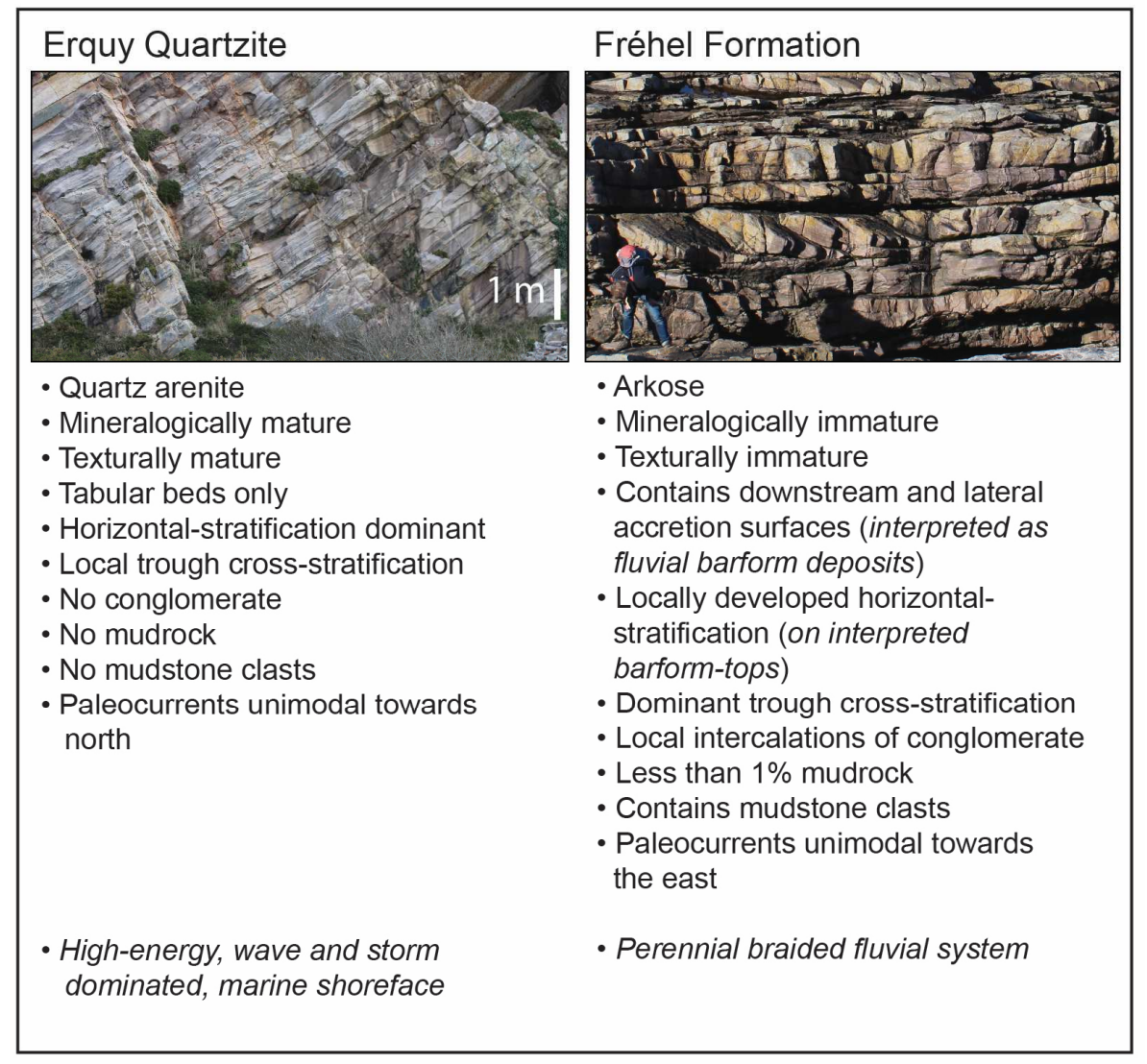

\section{Fig. S10}

Example case study where marine and non-marine depositional environments could be interpreted through an assessment of the balance and combination of the sedimentary characteristics of the two formations. 


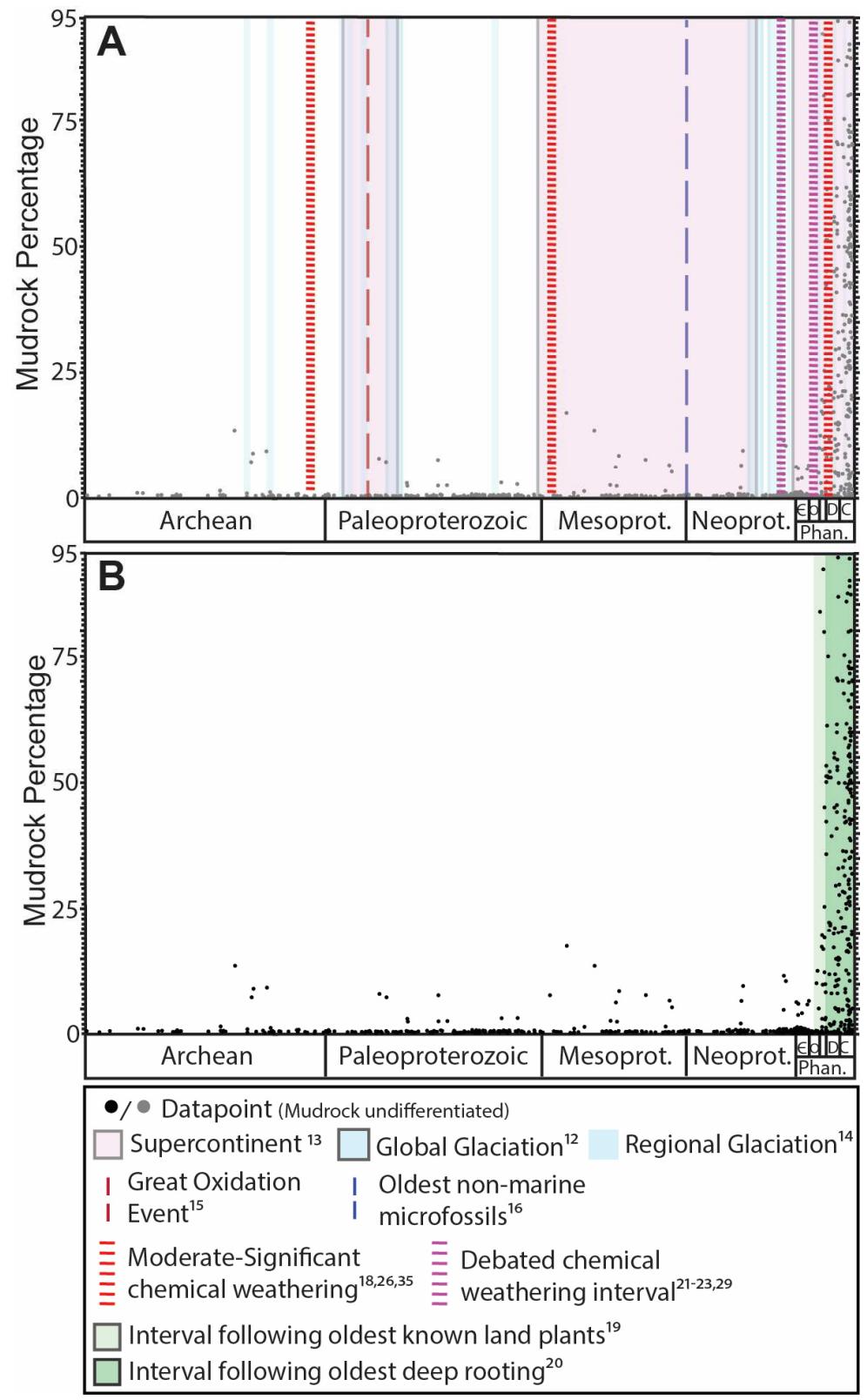

Fig. S11

Proportion of mudrock within alluvial successions of different ages with major episodic, cyclic and unidirectional changes in the Earth system shown. A) Tectonic, climatic and atmospheric changes. B) Paleobotanic changes. 


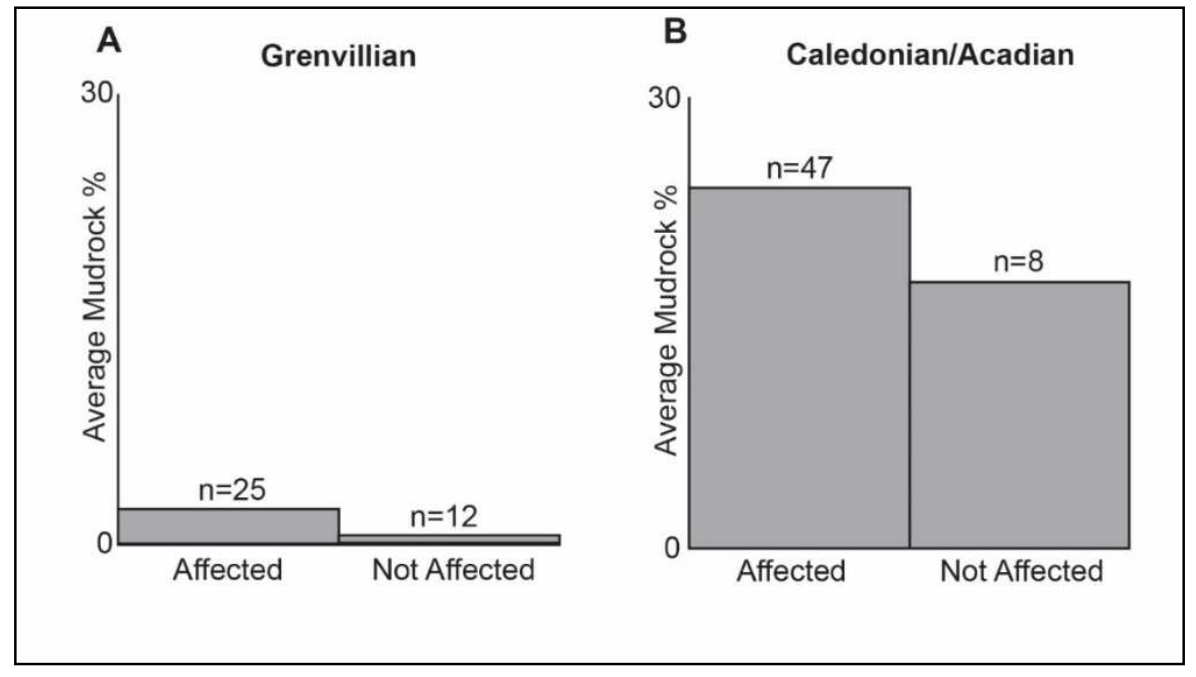

\section{Fig. S12}

Histograms comparing mudrock percentage in worldwide alluvium deposited during intervals of orogenic events. A) Affected (deposited neighbouring orogeny) and not affected (deposited away from orogeny) by the Grenvillian Orogeny (1100-900 Ma); B) Affected and not affected by the Caledonian/Acadian Orogeny (440-390 Ma). 

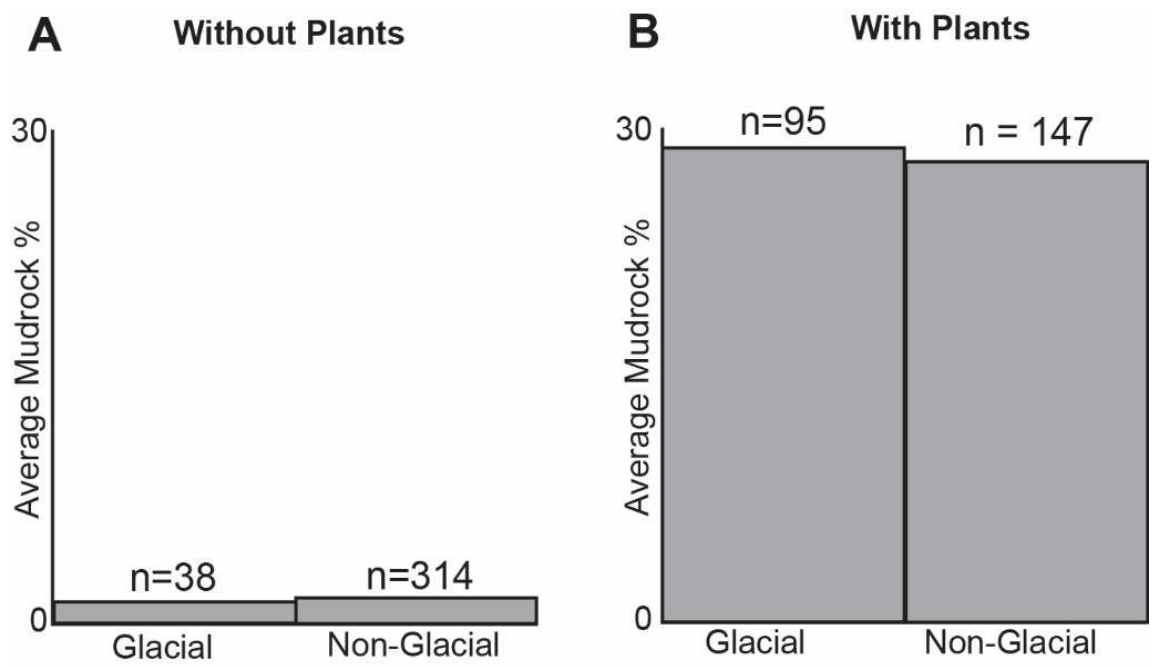

\section{Fig. S13}

Histogram plots comparing average mudrock percentage in worldwide alluvium. (A) Deposited during glacial intervals versus non-glacial intervals in the absence of land plants; (B) Deposited during glacial intervals versus non-glacial intervals in the presence of land plants. 


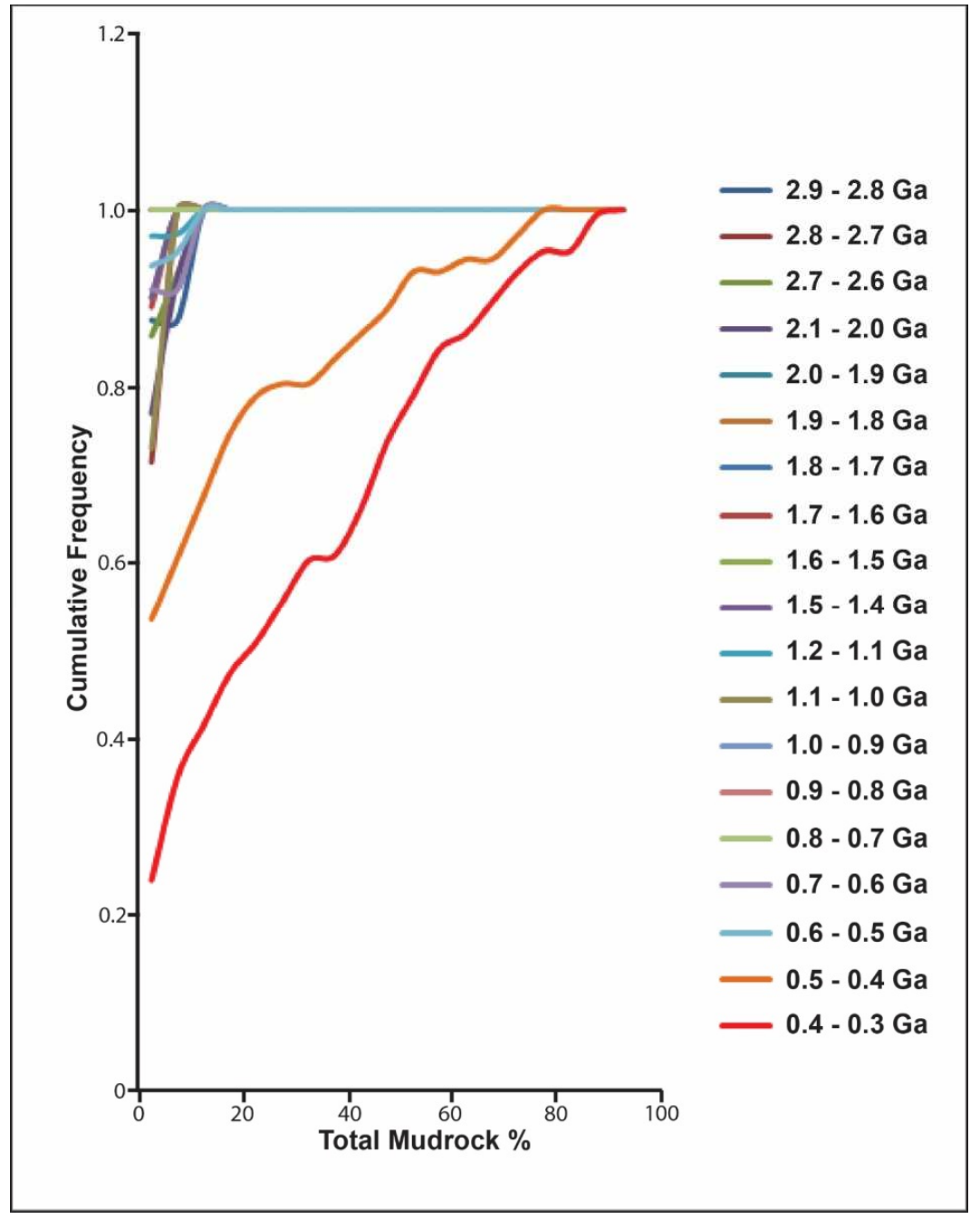

Fig. S14

Line graphs showing cumulative frequency and total mudrock percentage for each 100 million year interval where there are 7 or more case studies. Two lines recording intervals after plant evolution (0.5-0.4 Ga and 0.4-0.3 Ga) distanced from earlier lines. 


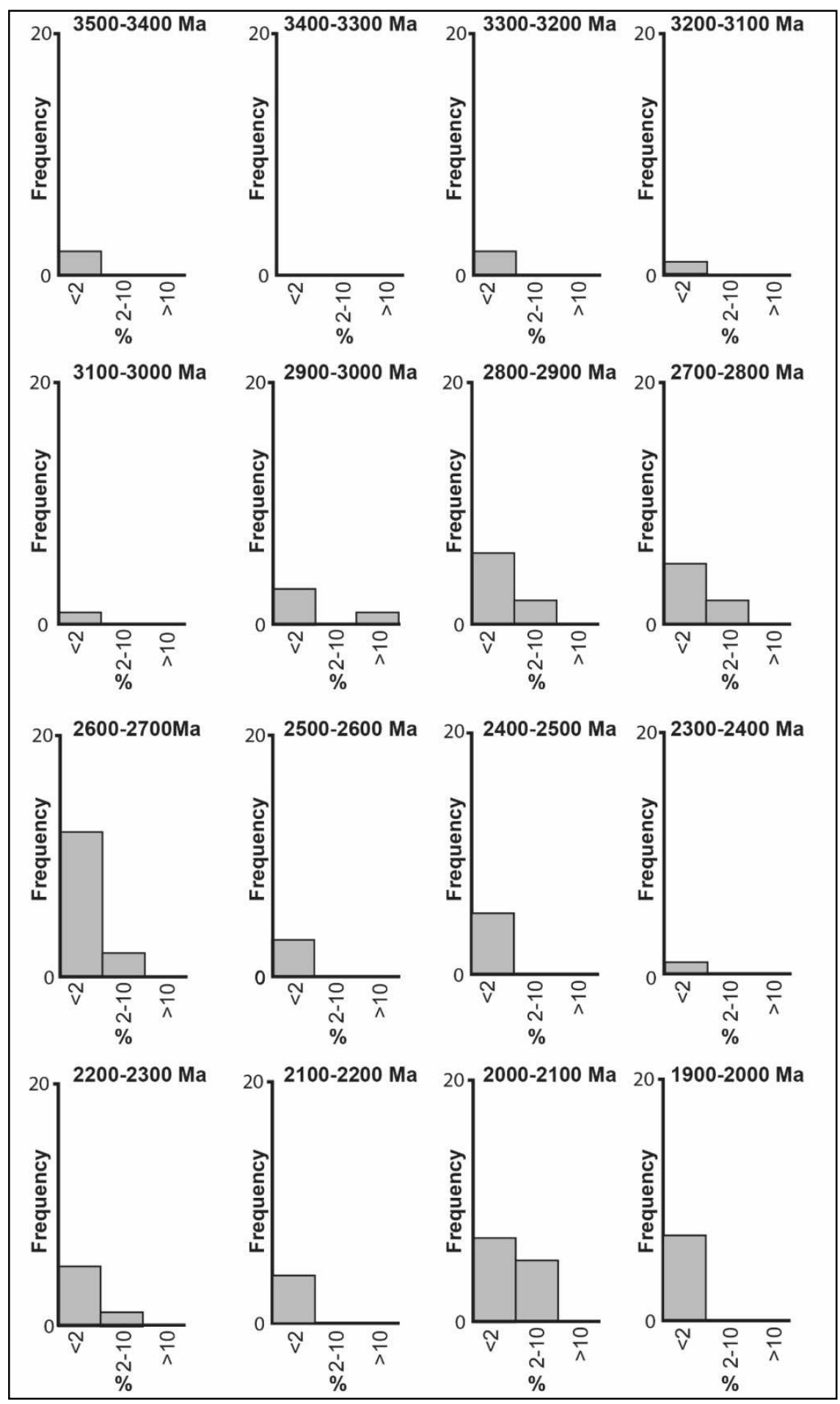

Fig. S15 (continued overleaf)

Histograms showing the frequency of mudrock distributions of each 100 million year interval in the database. Note increase in mudrock content during bin encompassing Ordovician and Silurian (400-500 Ma). 


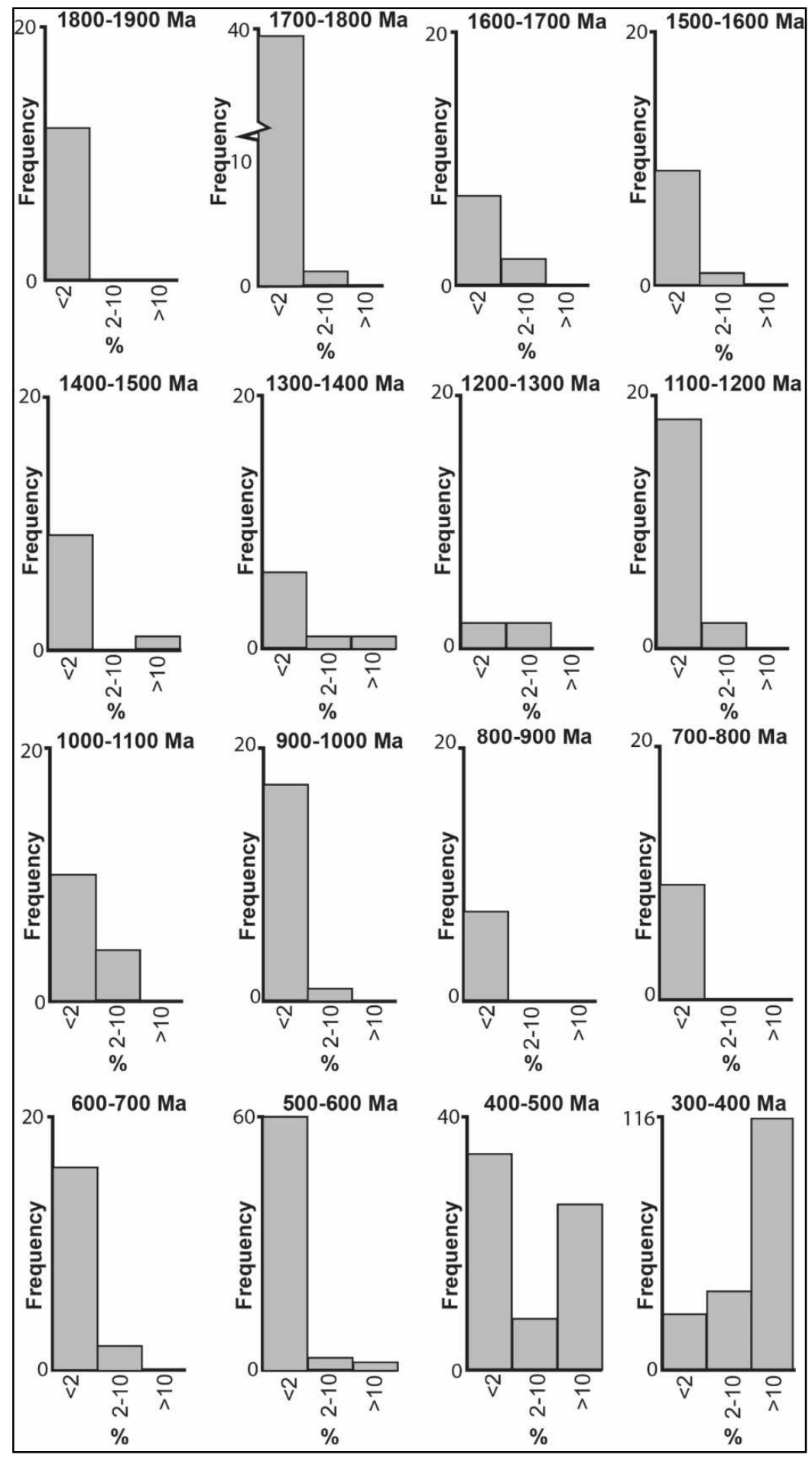




\section{Additiional Data (separate file)}

Table S1. Database of alluvial mudrock. Values highlighted in grey indicate mudrock proportion was calculated from published stratigraphic logs.

\section{References and notes}

38. Web of Science Service for UK Education. http://wok.mimas.ac.uk

39. Georef. http://www.agiweb.org/georef/

40. Google Scholar. https://scholar.google.com/

41. The BGS Lexicon of Named Rock Units. http://www.bgs.ac.uk/lexicon/

42. USGS National Geologic Map Database.

http://ngmdb.usgs.gov/Geolex/geolex_home.html

43. WEBLEX Canada. http://weblex.nrcan.gc.ca/weblexnet4/weblex_e.aspx

44. Australian Stratigraphic Units Database - Geoscience Australia.

http://dbforms.ga.gov.au/www/geodx.strat_units.int

45. Gradstein, F.M., Ogg, J.G., Hilgen, F.J. On The Geological Time Scale. Newsletters on Stratigraphy 45/2, 171-188 (2012).

46. Ronov, A.B. Phanerozoic transgressions and regressions on the continents: A quantitative approach based on areas flooded by the sea and areas of marine and continental deposition. Am. J. of Sci. 294, 777-801 (1994).

47. Ulmer-Scholle, D.S., Scholle, P.A., Schieber, J., Raine, R.J. A Color Guide to the Petrography of Sandstones, Siltstones, Shales and Associated Rocks. (American Association of Petroleum Geologists, Tulsa, OK, 2014). 
48. Dalrymple, R.W., Narbonne, G.M., Smith, L. Eolian action and the distribution of Cambrian shales in North America. Geology, 13, 607-610 (1985).

49. Davies, N.S., Gibling, M.R., Rygel, M.C. Alluvial facies during the Palaeozoic greening of the land: case studies, conceptual models and modern analogues. Sedimentology, 58, 220-258 (2011).

50. Weissmann, G. et al. Fluvial form in modern continental sedimentary basins: Distributive fluvial systems. Geology 38, 39-42 (2010).

51. Fielding, C.R. et al. Tributary, distributary and other fluvial patterns: What really represents the norm in the continental rock record? Sedimentary Geology 261-262, $15-32(2012)$.

52. Sadler, P.M. Sediment Accumulation Rates and the Completeness of Stratigraphic Sections. The J. Geol. 89, 569-584 (1981).

53. Nyberg, B., Howell, J.A. Is the present the key to the past? A global characterization of modern sedimentary basins. Geology 43, 643-646 (2015).

54. Rubinstein, R.Y., Kroese, D.P. Simulation and the Monte Carlo method. John Wiley \& Sons (2016).

55. Press, W. H., Flannery, B. P., Teukolsky, S. A., Vetterling, W. T. KolmogorovSmirnov Test. Numerical recipes in FORTRAN: the art of scientific computing, 617620 (1992).

56. Alroy, J. et al. Phanerozoic trends in the global diversity of marine invertebrates. Science 321, 5885 (2008). 
57. Miall, A.D. The Geology of Fluvial Deposits. Springer (1996).

58. Miall, A.D. Fluvial Depositional Systems. Springer (2014).

59. Davies, N.S. et al. Marine influence in the Upper Ordovician Juniata Formation (Potters Mills, Pennsylvania): implications for the history of life on land. Palaios 25, $527-539(2010)$

60. Davies, N.S., Gibling, M.R. Early Cambrian metazoans in fluvial environments, evidence of the non-marine Cambrian radiation: COMMENT. Geology 40, 270 (2012).

61. Weller, O.M., St-Onge, M.R. Record of modern-style plate tectonics in the Palaeoproterozoic Trans-Hudson orogeny. Nature Geoscience 10, 305-311 (2017).

62. Jones, D.S. et al. Chemostratigraphy of an Ordovician-Silurian carbonate platform: $\delta^{13} \mathrm{C}$ records below glacioeustatic exposure surfaces. Geology 43, 59-62 (2015).

63. Berner, R.A. The Phanerozoic Carbon Cycle: $\mathrm{CO}_{2}$ and $\mathrm{O}_{2}$. Oxford, UK: Oxford Univ. Press (2004).

64. Clarke, J.T., Warnock, R.C.M., Donoghue, P.C.J. Establishing a time-scale for plant evolution. New Phytol. 192, 266-301 (2011).

65. Karol, K.G., McCourt, R.M., Cemino, M.T., Delwiche, C.F. The closest living relatives of land plants. Science 294, 2351 (2001).

66. Watchorn, M.B. Fluvial and tidal sedimentation in the 3000 Ma Mozaan basin, South Africa. Precamb. Res. 13, 27-42 (1980). 
67. Andersen, L.S., Unrug, R. Geodynamic evolution of the Bangweulu Block, northern Zambia. Precamb. Res. 25, 187-212 (1984).

68. Daly, M.C., Unrug, R. The Muva Supergroup in Zambia-a craton to mobile belt sedimentary sequences. Trans. Geol. Soc. S. Afr. 85, 155-165 (1982).

69. Fralick, P., Zaniewski, K. Sedimentology of a wet, pre-vegetation floodplain assemblage. Sedimentology 59, 1030-1049 (2012).

70. Khalaf, E.E.D.A.H. Stratigraphy, facies architecture, and palaeoenvironment of Neoproterozoic volcanics and volcaniclastic deposits in Fatira area, Central Eastern Desert, Egypt. J. Afr. Earth Sci. 58, 405-426 (2010).

71. Fambrini, G.L., Janikian, L., de Almeida, R.P., Fragoso-Cesar, A. Evolução tectônica e estratigráfica do Grupo Santa Bárbara (Ediacarano) na Sub-Bacia Camaquã Central, RS, sul do Brasil: registro de sedimentação continental na assembléia do Gondwana. Comunicaçõe Geológicas 101, 39-54 (2014). 